\title{
Öğretmen Yetiştirme Üzerine Bir Model Önerisi: STEM Öğretmen Enstitüleri Eğitim Modeli
}

\author{
A Model Proposal for Teacher Training: STEM Teacher Institutes \\ Training Model \\ Bekir YILDIRIM**
}

• Geliș Tarihi: 04.07.2019 • Kabul Tarihi: 30.12.2019 • Çevrimiçi Yayın Tarihi: 10.02.2020

\begin{abstract}
$\ddot{\mathbf{O} z}$
Bu çalışmanın amacı, öğretmenlerin STEM eğitimiyle ilgili mesleki gelişimlerini sağlamaya yönelik bir öğretim modeli önerisinde bulunmaktır. Çalışma kapsamında, oluşturulan STEM eğitimi öğretmen modeline "STEM Öğretmen Enstitüleri Eğitim Modeli (SÖEEM)" adı verilmiştir. Araştırmanın çalışma grubunu farklı branşlarda görev yapmakta olan 40 öğretmen oluşturmuştur. Araştırma nitel araştırma yöntemlerinden özel durum çalışması desenine uygun olarak tasarlanmıştır. SÖEEM modelinin ortaya konulma sürecinde adımlarının belirlenmesi için doküman analizi, görüşme ve ders planı incelemesi yapılmıştır. Doküman incelemeleri sonucunda, SÖEEM modelinin sekiz aşamadan oluştuğu bulunmuştur. Görüşmeler sonucunda, öğretmenler STEM eğitimi konusunda kendilerini yeterli hissetmedikleri, lisans eğitimlerinin yeterli olmadığını, ders planı hazırlarken zorlandıklarını ve STEM okuryazarı olmadıklarını düşünmektedir. Dahası, öğretmenler STEM eğitimleri sırasında problemler yaşadıklarını da ifade etmiştir. Ders planı inceleme sonucunda ise, öğretmenler hazırladıkları ders planlarında özellik de STEM alanlarını entegre etme konusunda zorlandıkları tespit edilmiştir. Elde edilen bu sonuçlar 1şı̆̆ında, STEM Öğretmen Enstitü Eğitim Modeli tasarlanmıştır. Bu model ile öğretmen eğitimleri için ortak bir mesleki gelişim programının geliştirilmesi hedeflenmiştir.
\end{abstract}

Anahtar sözcükler: STEM, öğretmen, öğretmen eğitimi, model

Atıf:

Yıldırım, B. (2020). Öğretmen yetiştirme üzerine bir model önerisi: STEM öğretmen enstitüleri eğitim modeli. Pamukkale Üniversitesi Eğitim Fakültesi Dergisi, 50, 70-98.doi: 10.9779/pauefd.586603

\footnotetext{
* Bu çalışma 12-14 Nisan 2019 tarihleri arasında gerçekleşen Fen, Matematik, Uluslararası Girişimcilik ve Teknoloji Eğitimi Kongresi'nde sözlü bildiri olarak sunulmuştur.

Doç. Dr., Muş Alparslan Üniversitesi Eğitim Fakültesi, ORCID ID: 0000-0002-5374-4025, bekir58bekir@gmail.com
} 


\begin{abstract}
The purpose of the research was to present an educational model for professional development in STEM education. The STEM professional development model was called as "STEM Teacher Institutes Education Model (STIEM)". The study group consisted of 40 teachers from different areas. The research was designed in accordance with the case study design among the qualitative research methods. Document analysis, interview and lesson plan analysis were carried out to determine the steps in the process of revealing STIEM model. As a result of document analysis, it was comprehended that the STIEM model consisted of eight stages. As a result of the interviews, the teachers thought that they did not feel sufficient about STEM education, that their undergraduate education was not sufficient, that they had difficulty in preparing lesson plans, and that they were not STEM literate. Moreover, the teachers stated that they had problems during STEM trainings. As a result of the lesson plan analysis, it was concluded that the teachers had difficulty in integrating especially STEM fields into their lesson plans. The aim of the model to develop a common professional development program for teacher training.
\end{abstract}

Keywords: STEM, teacher, teacher training, model

\title{
Cited:
}

Y1ldırım, B. (2020). A model proposal for teacher training: STEM teacher institutes training model.

Pamukkale Üniversitesi Eğitim Fakültesi Dergisi, 50, 70-98.doi: 10.9779/pauefd.586603 


\section{Giriş}

Bilim ve teknolojide meydana gelen hızlı değişim, toplumların sağlıktan eğitime kadar birçok farklı alanda değişim yaşamasına neden olmuştur. Bu değişim ile birlikte, bireylerden beklenen bilişsel, duyuşsal ve psiko-motor özellikler de değişmiştir. Bilişsel, duyuşsal ve psiko-motor becerilerde meydana gelen bu değişimler ülkelerin eğitim anlayışlarını da değiştirmiştir. Değişen eğitim anlayışı ile birlikte ülkeler, eleştirel düşünebilen, problem çözme becerisine sahip, yaratıcı, müzakere yapabilen, bilişsel esnekliğe ve duygusal zekaya sahip bireyler yetiştirme üzerinde durmuştur (Çepni ve Ormanc1, 2018). Bu yüzden ülkeler iş dünyasının talep ettiği STEM becerileri ile donanımlı birey ihtiyaçlarını karşılayabilmek (McPherson ve Anid, 2014) için eğitim sistemlerinde değişikliklere gitmiş ve yeni eğitim yaklaşımlarını benimsemiştir (Freeman, 2013; Jon ve Chung, 2013). Bu eğitim yaklaşımlarından biri de STEM eğitim yaklaşımıdır. STEM eğitimi, bilim, teknoloji, mühendislik ve matematik alanlarının entegre bir şekilde günlük yaşamla ilişkilendirilerek verildiği bir eğitim yaklaşımıdır (Çakır, Yalçın ve Yalçın, 2019). Bu eğitim yaklaşımı 21. yy iş dünyası için gerekli eleştirel düşünme, işbirliği, yaratıcılık ve etkili iletişim becerilerinin gelişmesini sağladığg (Katehi, Pearson ve Feder, 2009) gibi teknolojik gelişmeleri de tetikleyerek ekonominin canlanmasını sağlamaktadır.

STEM eğitiminin, iş dünyası için gerekli becerilere sahip bireylerin yetişmesi ve ekonomi için itici bir güç oluşturması ülkelerin formal ve infromal eğitim ortamlarında STEM eğitimine yer verilmesini sağlamıştır. STEM eğitiminin formal ve informal eğitim ortamlarından uygulanmasında en önemli faktörlerden biri öğretmendir. Öğretmen, eğitim için öğrencilerin cesaretlendirilmesi ve hazırlanmasında hayati bir rol oynar (Braga, 1972; Gökdere ve Çepni, 2003). Öğretmenin eğitim siteminde hayati bir yerinin olması STEM eğitiminin sınıflarda uygulanmasında öğretmenlere önemli bir rolün düştüğünü göstermektedir (Çorlu, Capraro ve Capraro, 2014; Timur ve İnançl1, 2018; Türk, Kalaycı ve Yamak, 2018). Bu yüzden, U.S. Deparment of Education (2010) STEM eğitiminin öğretimi için K-12 öğretmenlerinin hazırlanmasının ulusal bir öncelik olduğunu vurgulamakta ve STEM öğretimi için bir programın hazırlanması gerektiği üzerinde durulmaktadır. Çünkü, STEM eğitiminde nitelikli öğretmenlerin hazırlanması öğrencilerin yüksek akademik standartlara ulaşmasında önemlidir. Örneğin, öğretmenlerin fen bilimleri ve matematik yeterlilikleri öğrencilerin başarıları ile ilişkili (Hibpshman, 2007) olduğu düşünüldüğünde öğretmenlerin STEM eğitimiyle ilgili yeterlilikleri ile öğrenci başarısı arasında da bir ilişkinin olduğu söylenebilir. Benzer şekilde, Eckman, Williams ve Silver-Thorn (2016) nasıl matematiği etkili bir şekilde sınıfta öğretebilmek için matematik bilgilerini, matematik kavramlarını ve kurallarını bilmek gerekiyorsa STEM eğitimini de etkili şekilde öğretebilmek için tüm STEM alanlarına hâkim olması gerekmektedir. Diğer bir deyişle, öğretmenlerin STEM eğitimi için özel tasarlanmış güçlü bir pedogojik eğitime ihtiyaçları vardır (The President's Council of Advisors on Science and Technology [PCAST], 2010). Ancak STEM eğitimi konusunda öğretmenlerin her alanda sağlam bilgiye sahip olması için gerekli olan mesleki gelişim programlarının eksik olması öğrencilerin düşük performans göstermelerine sebep olmaktadır (Ejiwale, 2013). Nitekim, STEM entegrasyonun başarılı bir şekilde yapılabilmesi ve sınıflarda uygulanabilmesi için öğretmenlerin konuya hâkim olmaları önemlidir (Pang ve Good, 2000). Öğretmenlerin alan 
bilgisinin yeterli düzeyde olmaması STEM entegrasyonunun sağlanmasını güçleştirmektedir (Stinson Harkness, Meyer ve Stallworth, 2009).

Etkili bir öğretim için alan ve pedagoji bilgisi önemlidir (Stohlmann, Moore ve Roehrig, 2012). Nitekim, Margot ve Kettler (2019) öğretmenlerin etkili STEM öğretimini gerçekleştirebilmeleri için STEM eğitimi mesleki gelişim programları ile desteklenmelerinin gerekliliğini vurgulamıştır. Bu durumlar, STEM öğretmenlerinin yetiştirilmesi için mesleki gelişim programlarının hazırlanmasına neden olmuştur (Ejiwale, 2013). Bu yüzden, öğretmenlerin STEM eğitimini sınıflarında uygulayabilmesi için STEM eğitimi mesleki gelişim programları planlanmalıdır (Du, Liu, Johnson, Sondergeld, Bolshakova ve Moore, 2018). Bu mesleki gelişim programları, bir üniversiteye bağlı ya da bağımsız bir kuruluş olarak genellikle araştırma yapan ve bazı durumlarda öğretime yer veren enstitüler tarafından verilmelidir (Türk Dil Kurumu [TDK], 2019). Bu eğitimleri öğretmen yetiştirmek için kurulmuş olan eğitim enstitüleri de verebilir. Bu noktada eğitim enstitüleri STEM mesleki gelişim programlarını, pedagoji bilgisi, alan bilgisi, öğretmenlerin tutum ve inançları ile toplumun ve öğretmenlerin özel ihtiyaçlarına cevap verecek şekilde yapılandırmalıdır (Dass, 2001). Örneğin, 1940 yılında kurulan Köy Enstitülerinin temel amacı da hem köylerin öğretmen ihtiyacını karşılamak hem de kurulduğu yerin kalkınmasını sağlamaktır (Gedikoğlu, 1971). Köylerin öğretmen ihtiyacını karşılamak ve köylerin kalkınmasını sağlamak için kurulan köy enstitülerinin kurulma amaçları ile STEM eğitiminin bugün eğitim sisteminde kullanılması benzerlik göstermektedir. Nitekim, STEM mesleki gelişim programları ile hem STEM eğitimi için yüksek nitelikte öğretmen ihtiyacını karşılanmak hem de toplumsal gelişimi sağlamak yer almaktadır (National Research Council [NRC], 2011; Reeve, 2015). Bu sebeple, STEM eğitimi konusunda yüksek nitelikte öğretmenlerin yetiştirilmesi için öğretmenlere STEM eğitimi konusunda yeterli mesleki bilginin verilmesi önem arz etmektedir. Ancak, alanyazın incelendiğinde, çoğu çalışmada STEM eğitiminin önemi vurgulansa da öğretmenlerin büyük bir oranının STEM eğitimi konusunda kendisini yeterli hissetmediği ve STEM öğretmenlerinin gelişimini sağlamak için bir STEM eğitimi programının olmadığı anlaşılmaktadır (NRC, 2011). Nitekim çoğu araştırma raporlarında da öğretmenlerin STEM eğitimi konusunda zorlandığı (Jho, Hong ve Song, 2016) ve birçok çalışmada ise STEM eğitimiyle ilgili kavram yanılgılarının olduğu vurgulanmıştır (Akgündüz, 2016; Hossain ve Robinson, 2012; Morrison, 2006; Y1ldırım ve Selvi, 2016).

$\mathrm{Bu}$ nedenle, STEM eğitimi için gerekli becerilerin kazandırılmasında öğretmen mesleki gelişim programlarına birinci dereceden odaklanılması gerekmektedir. Ancak çoğu mesleki gelişim programının kısa süreli yapılması öğretmenlerin mesleki gelişim ihtiyaçlarının karşılayamamaktadır (Rinke, Gladstone-Brown, Kinlaw ve Cappiello, 2016). Alanyazın incelendiğinde, öğretmenlerin mesleki gelişimlerini sağlayabilmeleri için en az 80 saatlik bir eğitim süresinin olması, öğretmenlerin öğrendikleri bilgileri sınıflarında uygulamalarına imkan verilmesi ve sınıf içindeki uygulamalarının desteklemesi amacıyla bu sürenin akademik yıl içine entegre edilerek yapılmasının önemli olduğu vurgulanmıştır (Jhonson ve Fargo, 2010; Supovitz ve Turner, 2000).

$\mathrm{Bu}$ bağlamda bu çalışmada, öğretmenlerin STEM eğitimine yönelik mesleki gelişimlerini sağlayacakları STEM Öğretmen Enstitüleri Eğitim Modeli (SÖEEM) önerilmiştir. Önerilen bu model, Türkiye'de öğretmenlere yönelik olarak önerilen bir STEM öğretmen eğitim modeli olması açısından önemlidir. Bu model ile öğretmenlerin STEM öğretmen mesleki 
yeterliliklerinin geliştirilmesi amaçlanmıştır. $\mathrm{Bu}$ amaç doğrultusunda, bu model ile öğretmenlerin "STEM eğitimi mesleki bilgisi”, "STEM eğitimi meslek becerileri” ve "STEM eğitiminde Tutum ve değerler" yeterlilik alanlarının gelişmesine katkı sağlaması beklenmektedir. Dahası, bu çalışma STEM eğitiminde öğretmenlerin mesleki yeterliliklerinin geliştirilmesi için yapılması gereken aşamaları içermesinden dolayı bu alanda yapılan ilk çalışmayı oluşturmaktadır. Ayrıca bu model öğretmenlerin mesleki gelişimlerini sağlayacak şekilde en az 80 saatlik bir eğitim sürecini kapsayacak şekilde tasarlanmıştır. Çünkü, alanyazında özellikle öğretmenlerin bu alanda mesleki yeterliliklerinin gelişmesi için en az 80 saatlik bir süreye ihtiyaç olduğu vurgulanmaktadır. Model bu özelliği nedeniyle, diğer STEM öğretmen modellerinden farkl111k göstermektedir. Dahası, SÖEEM modeli ile STEM öğretmen eğitimlerinin belli bir standartta verilmesi için zemin oluşturulacağı düşünülmektedir. $\mathrm{Bu}$ yüzden, bu çalışmanın bundan sonra yapılacak olan STEM öğretmen eğitim modelleri ve STEM öğretmen eğitimleri için temel oluşturacağı söylenebilir. Ayrıca, alanyazın incelendiğinde, STEM eğitimleri ve öğretmen eğitimlerinin birleştirildiği birçok çalışmanın olduğu da anlaşılmaktadır (Can ve Uluçınar-Sağır, 2018; Çevik, Danıştay ve Yağcı, 2017; Karakaya, Ünal, Çimen ve Yılmaz, 2018; Tosmur - Bayazıt, Akaygün, Demir ve Aslan - Tutak, 2018; Wang, Moore, Roehrig ve Park, 2011). Ancak bu çalışmalarda eğitimlerin hangi mesleki gelişim programına göre işlendiğine dair bir bilgiye rastlanmamış olması bu çalışmayı önemli kılmaktadır. Kısacası, bu çalışmanın amacı, öğretmenlerin STEM eğitimiyle ilgili mesleki gelişimlerini sağlamaya yönelik STEM Öğretmen Enstitüleri Eğitim Modeli (SÖEEM) önerisinde bulunmaktır.

\section{Yöntem}

\section{Araştırma Deseni}

Araştırma kapsamında, öğretmenlerin STEM eğitimiyle ilgili mesleki yeterliliklerinin geliştirilmesini sağlamak amaciyla SÖEEM önerisinde bulunulmuştur. Bu amaç doğrultusunda, araştırma nitel araştırma yöntemlerinden özel durum çalışması desenine uygun olarak tasarlanmıştır. Özel durum çalışması, farklı nitel veri toplama yöntemlerinin (görüşme, gözlem, doküman analizi gibi) bir arada kullanıldığı, bir olayın gerçek ortamı içinde bütüncül bir şekilde ortaya konulmasına imkan veren ve araştırmanın yürütülmesinde araştırmaciya esneklik sağlayan araştırmadır (Silverman, 2013; Yin, 2017). Çalışma kapsamında, ilk olarak model için uygun olabilecek adımların neler olduğuna yanıt aranmış ve SÖEEM modeli adımları doküman analiziyle belirlenmiştir. İkinci olarak, öğretmenlere bireysel ve grup olarak ders planı hazırlatılmıştır. Öğretmenlere hazırlamış oldukları ders planlarını sınıflarında uygulanması için 1 hafta süre verilmiş ve süreç sonucunda öğretmenler ile görüşmeler yapılmıştır. Görüşmeler sonucunda, ders planlarında güncellemeler gerçekleştirilmiştir. Bu süreçte doküman analizleri, görüşmeler ve ders planı incelemeleri yapılmış ve sonucunda SÖEEM modeli için aşamalar netleştirilmiştir.

\section{Çalışma Grubu}

Çalışma grubu oluşturulurken olasılıklı olmayan örnekleme yöntemlerinden amaca yönelik örnekleme yöntemi ve bu örnekleme içinde yer alan kolay ulaşılabilir durum örneklemesi seçilmiştir. Bu örneklemede, araştırmacı çalışmayı yürüteceği kişilere kendisi karar verir ve çalışmanın amacına uygun olarak en uygun örneklemi seçer (Balcı, 2016). Çalışma kapsamında 
en uygun örneklemin seçilmesi araştırmacıya zaman ve kolaylık sağlar (Platton, 2002). Bu doğrultuda, araştırmanın çalışma grubunu, Türkiye'de yer alan Büyükşehirlerden birinde görev yapmakta olan 40 öğretmen oluşturmuştur. Çalışma grubu oluşturulurken; (1) STEM öğretmen eğitimi yapılacağı internet ortamında duyurulmuş, (2) internet ortamında başvurular alınmış ve (3) başvuru yapan kişilere süreç hakkında bilgi verilerek çalışmaya gönüllü olarak katılacağını ifade eden öğretmenler çalışmaya dahil edilmiştir. Çalışma grubunda yer alan öğretmenlere ilişkin betimsel bilgiler Tablo 1'de verilmiştir.

Tablo 1. Öğretmenlere İlişskin Betimsel Bilgiler

\begin{tabular}{lll}
\hline Tema & Kodlar & $\mathrm{f}$ \\
\hline Cinsiyet & Erkek & 9 \\
& Kadın & 31 \\
\hline Deneyim & $1-10$ yıl & 20 \\
& $11-20$ yıl & 16 \\
& 21 ve üstü & 4 \\
\hline Branş & Okulöncesi Öğretmenliği & 8 \\
& Teknoloji-Tasarım Öğretmenliği & 8 \\
& Matematik Öğretmenliği & 8 \\
& Fen Bilimleri Öğretmenliği & 8 \\
& Bilişim Teknolojileri Öğretmenliği & 4 \\
& Sinı Öğretmenliği & 4 \\
\hline
\end{tabular}

Tablo 1 incelendiğinde, çalışma grubunun büyük çoğunluğunu kadın öğretmenlerin oluşturduğu, öğretmenlerin çoğunun deneyiminin 1-10 yıl arasında değiştiği ve öğretmenlerin farklı branşlardan olduğu tespit edilmiştir.

\section{Araștırma Süreci}

SÖEEM modeli, ATGUD (ADDIE) tasarım modeline göre geliştirilmiştir (Dick ve Carey, 1996). ATGUD tasarım modeli, Analiz, Tasarım, Geliştirme, Uygulama ve Değerlendirme (ADDIE, Analyze, Design, Develop, Implement, Evaluate) aşamaları olmak üzere beş aşamadan meydana gelen bir öğretim tasarım modelidir. Öğretim tasarım modeli olan ATGUD modeli, tüm öğretimler için uygun olabilen temel bir model olması, diğer öğretim tasarımı modellerinin bileşenlerini içermesi ve öğretimin temel tanımlarını kapsamasından dolayı SÖEEM modelinin oluşturulmasında tercih edilmiştir. SÖEEM modelinin oluşturulma süreci detaylı olarak anlatılmıştır.

\section{Pilot Çalışma}

ATGUD modelinin SÖEMM modeli geliştirmek için uygun olup olmadığını tespit etmek için öncelikle STEM öğretmen eğitimlerinden birinde pilot çalışma olarak uygulanmıştır. Pilot uygulama sonucunda ATGUD tasarım modelinin SÖEMM için uygun bir model olduğuna karar verilmiştir.

\section{Analiz}

$\mathrm{Bu}$ aşama, ihtiyaç analizi, katılımcı analizi, hedef kitlenin belirlenmesi, problemin tanımlanması, görev ve öğretim analizinden oluşmaktadır.

İhtiyaç analizi ve hedef kitlenin belirlenmesi, çalışma kapsamında STEM eğitimleri ile ilgili ihtiyaç analizi yapıldıktan sonra katılımcı analizi gerçekleştirilmiş ve hedef kitle belirlenmiştir. Hedef kitle belirlendikten sonra çalışmaya "STEM öğretmen eğitimleri nasıl 
olmalıdır?" sorusu ile başlanmıştır. Görev analizinde görev, problem analizinden elde edilen sonuca göre, öğretmenlerin STEM eğitimleri konusunda yeterliklerini geliştirecek bir model önerisinde bulunulmak olarak belirlenmiştir. Öğretim analizi, nelerin öğretilmesi ile gerekli analizi içermekte olup bu kısımda STEM alanlarına ilişkin bilgiler dikkate alınmıştır.

\section{Tasarım: Ö̆̆retim adımların belirlenmesi}

$\mathrm{Bu}$ aşamada, öğretimin nasıl gerçekleşeceğine ilişkin tasarım yapılır. Tasarımlar, analiz aşamasında belirtilen ihtiyaçları karşılayacak şekilde yapılmalıdır. Öğretim adımlarının tasarlanmasında kullanılacak olan dokümanlar alan yazını taraması sonucunda elde edilmiştir. Elde edilen dokümanlar analiz edilmiş ve tasarım gerçekleştirilmiştir. Tasarım sürecinde Yıldırım ve Şimşek'in (2011) belirlediği (1) dokümana ulaşma, (2) dokümanların orjinalliğini teyit etme, (3) dokümanların anlaşılması, (4) verilerin analizi ve (5) verilerin kullanılması aşamalarından yararlanılmıştır. Bu aşamalar aşağıda ayrıntılı şekilde açıklanmıştır. Bunlar:

Dokümana ulaşma: SÖEEM modelinin aşamalarının belirlenmesi için STEM eğitimi ve öğretmen eğitimlerine yönelik yapılan çalışmalara; STEM eğitiminde öğretmen eğitimleri, STEM Pedagojik Alan Bilgisi, Öğretmen Enstitüleri, STEM öğretmeni ve öğretmen kelimeleri ile Google Scholar, Web of Science, Science Direct ve Eric veri tabanlarında arama yapılarak ulaşılmıştır. Elde edilen 32 makaleden, STEM eğitiminde öğretmen eğitimi ve model önerisine uygun 17 makale belirlenmiştir. Öğretmen eğitimlerinin nasıl olması gerektiğini ele almayan, STEM öğretmen eğitimleri için mesleki gelişim programların yer almadığı, STEM eğitimlerinde verilmesi gerekenlerin neler olması gerektiği vurgulanmayan ve öğretmen eğitimlerinde uygulama aşamalarına yer vermeyen çalışmalar elenmiştir. Araştırma kapsamında elde edilen bu dokümanların kullanılmasının nedeni, önerilecek olan SÖEEM modelinin öğretim aşamaları ve içeriğinin belirlenmesini sağlamaktır. Araştırma kapsamında makalelere yer verilmesinin amacı, araştırmanın uygulanabilirliğini ve araştırmanın sınırlarını ortaya koyabilmektir. Bu doğrultuda incelenen çalışmalar Tablo 2'de listelenmiştir.

Tablo 2. İncelenen Dokümanlar

\begin{tabular}{ll}
\hline Doküman Türleri & İncelenen Kaynaklar \\
\hline & Aysal, (2005) \\
& Corlu, Capraro ve Capraro, (2014) \\
& Du vd. (2019) \\
& Eckman, Williams ve Silver-Thorn (2016) \\
& Gencer, Doğan, Bilen ve Can, (2019) \\
& Goodnough, Pelech ve Stordy (2014) \\
& Guzey, Tank, Wang, Roehring ve Moore, (2014) \\
& Jho, Hong ve Song, (2016). \\
& Margot ve Kettler (2019) \\
& Miller-Bolotin, (2018) \\
& Nagdi, Leammukda ve Roehrig, (2018) \\
& Ring, Dare, Crotty ve Roehrig, (2017) \\
& Rinke, Gladstone-Brown, Kinlaw ve Cappiello, (2016) \\
& Stohlmann, Moore ve Roehrig, (2012) \\
& Türk, Kalayc1 ve Yamak, (2018) \\
& Yildırım ve Şahin-Topalcengiz, (2018) \\
& Yildırım, (2018) \\
\hline
\end{tabular}

Bu dokümanlar SÖEEM modeli için gerekli aşmaların belirlenmesinde incelenmiştir. İnceleme sonucunda model için sekiz aşama belirlenmiştir. 
Orijinalliği Teyit Etme: SÖEEM modelinin öğretim aşamaları ve içeriğin belirlenmesinde ulaşılan çalışmaların orijinalliğinin sağlanması ortaya konulacak olan modelin geçerliliği için önem arz etmektedir. Elde edilen dokümanların Google Scholar, Web of Science, Science Direct ve Eric veri tabanlarında belirlenen anahtar kelimeler ile arama yapılmış ve ulaşılan makalelerin hangi dergilerde yayınlandığı incelenerek orijinalliği teyit edilmiştir.

Dokümanların Anlaşılması ve Analizi: SÖEEM modelinin öğretim aşamaları ve içeriğinin belirlenmesi için elde edilen dokümanlar derinlemesine incelenmiş ve diğer dokümanlar ile karşılaştırılarak aşamalar ve içerikler belirlenmiştir.

Dokümanlar Sonucunda Elde Edilen Verilerin Kullanılması: Doküman incelemesi sonucunda elde edilen verilere ilişkin bilgiler ayrıntılı ve detaylı şekilde bulgular kısmında verilmiştir.

\section{Gelişstirme aşaması: öğretim aşaması ve ders planlarının geliştirilmesi}

Öğretmenlerde mesleki gelişiminin sağlanması için en az 80 saatlik bir eğitimi verilmesi gerektiği vurgulanmıştır (Du vd., 2019). Bu yüzden öğretmenlere 80 saatlik STEM eğitimi programı geliştirilmiş ve verilmiştir. Hazırlanan 80 saatlik eğitime fen bilimleri, matematik, bilişim teknolojileri, sınıf, okulöncesi ve teknoloji-tasarım öğretmenleri olmak üzere altı farklı branştan öğretmenler gönüllü katılmıştır. Alanyazın incelendiğinde, STEM eğitimlerinde farklı branşlarda olan öğretmenler ile iletişimde olmanın önemli olduğu vurgulanmıştır (Noh ve Paik, 2014). Özellikle de farklı branşta yer alan öğretmenlerin STEM eğitimi için işbirliği içinde olması STEM eğitiminin doğasını anlamalarında ve mesleki gelişimlerinde önemlidir (Jho, Hong ve Song, 2016; Jhones ve Carter, 2007). Bu nedenle eğitim öncesinde, öğretmenler 4-6 kişilik gruplara ayrılmıştır. Oluşturulan grupların 4'ü farklı branşlardan (Fen Bilimleri, Matematik, Teknoloji-Tasarım ve Bilişim Teknolojiler Öğretmeni) öğretmenlerden oluşurken, 2 grup okulöncesi öğretmenlerinden, 1 grup sinıf öğretmenlerinden, 1 grup fen bilimleri öğretmenlerinden, 1 grup matematik öğretmenlerinden ve 1 grup teknoloji-tasarım öğretmenlerinden oluşturulmuştur. Alanyazın incelendiğinde, STEM alan bilgisinin ilköğretim ve ortaokul düzeyinde değişiklik gösterebileceği ve öğretmen eğitimlerinin değişeceği anlaşılmaktadır (Rinke vd., 2016). Bu sebepten dolayı, bazı gruplar homojen olarak oluşturtulurken bazı gruplar ise heterojen oluşturulmuştur. Çünkü, grupların ihtiyaç analizlerinin branş bazında tespit edilmesi için farklı gruplar oluşturulmuş ve eğitimlere geçilmiştir. 80 saatlik eğitim sürecine ilişkin bilgiler Şekil 1'de verilmiştir.

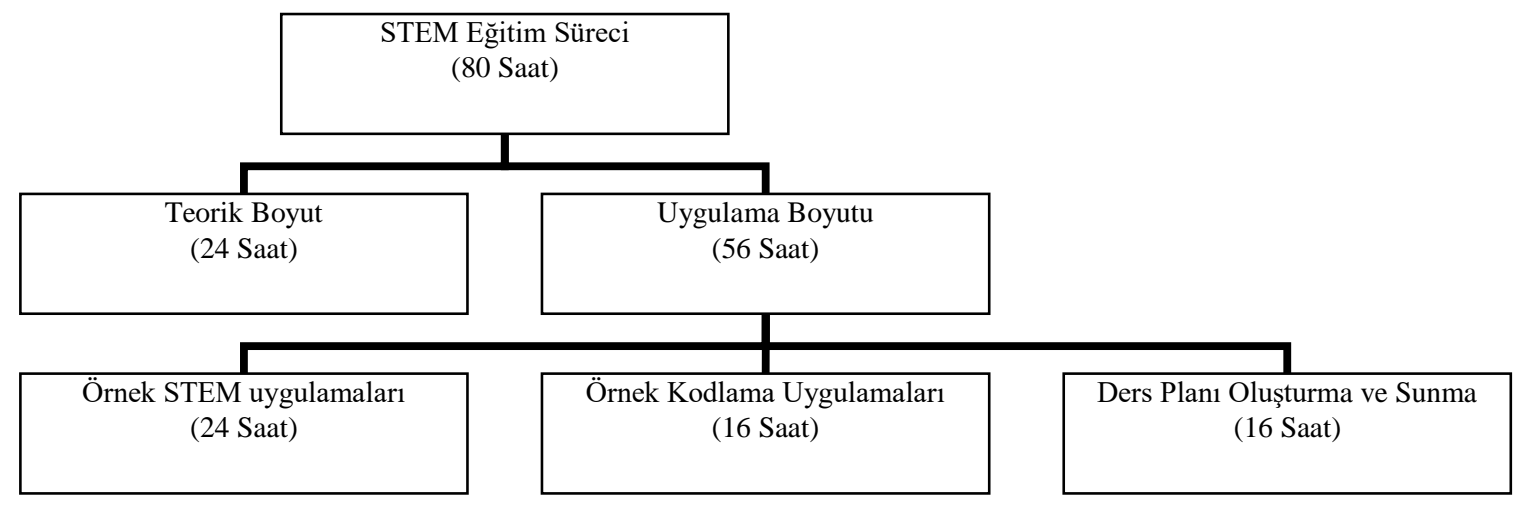

Şekil 1. 80 Saatlik Eğitim Sürecine İlişkin Bilgiler 
Eğitimler bitikten sonra ders planı hazırlama süreci bireysel ve grup olmak üzere iki farklı şekilde gerçekleşmiştir. Öğretmenlerin bireysel ve grup olarak ders planı hazırlamalarının sağlanmasının amacı, (1) bireysel olarak ders planı hazırlama sırasında yaşadıkları sıkıntılarının tespit etmek, (2) grup halinde çalışmanın önemini kavramak ve (3) grup çalışmasının ders planı hazırlamadaki avantajlarını ortaya koymaktır. $\mathrm{Bu}$ kapsamda, öğretmenlere, ders planı hazırlamaları için 90 dakikalık süre verilmiştir. Hazırlanan ders planlarında, (1) STEM eğitiminin doğasına uygunluk, (2) STEM alanlarına ilişkin bilgisine uygunluk, (3) öğretmeöğrenme süreçlerine uygunluk, (4) zaman açısından uygunluk, (5) hazırlandığı sınıf düzeyine uygunluk, (6) uygulanabilirlik ve (7) günlük yaşamla bağlantılı olmasına dikkat edilmiştir.

\section{Uygulama planlarının sunulmast}

Öğretmenler oluşturdukları ders planlarını bireysel ve grup olarak sunmuştur. Bireysel ders planlarının sunulması için her bir öğretmene 10 dakika ve soru sorulması için 5 dakika süre verilmiştir. Grup halinde ders planlarının sunulması için gruplara 10 dakika ve soru sorulması için de 10 dakikalık bir süre verilmiştir.

\section{Ders planlarının uygulanması ve görüşlerin alınması}

Öğretmenlere ders planlarını sınıflarında uygulamaları için 1 haftalık süre verilmiştir. Öğretmenler bu süreç içerisinde aynı sınıf düzeyinden iki farklı sınıfta (Bazı okullarda ise, tek sınıf mevcuttur) birer kez uygulamaları istenmiştir. Çünkü, tek sınıfta eksiklerin görülmesinin zor olacağı düşünülerek iki farklı sınıfta uygulama yapmaları istenmiştir. Öğretmenler sınıflarında ders planlarını uyguladıktan sonra öğretmenlerden ders planlarına iliş̧kin görüşlerini sunmaları istenmiş ve uygulama sonrasında ise öğretmenlerden görüşler alınmıştır.

\section{Değerlendirme: Ders planlarının güncellenmesi}

Öğretmenlerle yapılan görüşmeler 1şı̆̆ı̆nda, öğretmenler ders planlarında güncellemelere gitmiştir.

\section{Veri Toplama Araçları}

\section{STEM öğretmen enstitü eğitim modeli formu}

SÖEEM modelinin aşamalarını ortaya koymak için yarı yapılandırılmış görüşmelere yer verilmiştir. Araştırma kapsamında, yarı yapılandırılmış görüşme formuna yer verilmesinin amacı araştırmacıya görüşmenin gidişatını kendi elinde tutma fırsatı vermesidir (Merriam, 2009). Öğretmenlerin görüşmesinde kullanılan "STEM Öğretmen Enstitü Eğitim Modeli Formu (SÖEEMF)" 9 sorudan oluşmaktadır ve araştırmacı tarafından oluşturulmuştur. Araştırmacı 9 sorudan oluşan formun ilk halini oluşturduktan sonra iki uzmandan görüş almıştır. Birinci uzman, STEM eğitimi alanında çalışmalarını yapmış ve doktorasını bu alanda bitirmiştir. İkinci uzman ise, eğitim programları ve öğretimi alanında çalışmalarını yapmış ve doktorasını bu alanda bitirmiştir. Uzman görüşleri doğrultusunda, forma son hali verilmiştir. Görüşme formu STEM eğitimi almış üç ögretmene pilot çalışma olarak uygulanmıştır. Uygulamalar sırasında öğretmenlere, SÖEEMF forumda anlaşılmayan yerlerin olup olmadığı sorulmuş ve forma son hali verilmiştir. SÖEEM formuna ilişkin örnek sorular Şekil 2'de verilmiştir. 
1. Ders planı hazırlarken dikkat ettiğiniz özellikler nelerdir?

2. Ders planı hazırlamadaki zorluklar nelerdir?

Sonda: Grup olarak ders planı hazırlamanın kolaylıkları nelerdir?

3. Ders planlarınızı sınıfınızda uygularken yaşadığınız sıkıntılar nelerdir?

Sonda: Uygulama sırasında, ders planlarıma şunu da ekleseydim daha iyi olurdu dediğiniz yerler oldu mu?

\section{Şekil 2. Yarı yapılandırılmış görüşme formuna ilişkin örnek sorular}

\section{Araştırmanın Geçerliği ve Güvenirliği}

\section{Görüşme Sorularının Analizine İlişsin Geçerlik ve Güvenirlik}

Çalışma kapsamında elde edilen nitel veriler, içerik analizi yöntemiyle çözümlenmiştir. Araştırma kapsamında veriler ses kayıtları ve yarı yapılandırılmış görüşmeler aracılığıyla toplanmıştır. Elde edilen kayıtlar araştırmacı ve bir uzman yardımı ile yazıya aktarılmıştır. Yazıya aktarılan verilerin analizi ve yorumu dört aşamalı bir şekilde gerçekleştirilmiştir. Bu aşamalar dokümanlardan elde edilen verilerin işlenmesi, verilerin kodlanması, kodların düzenlenmesi, bulguların tanımlanması, yorumlanması şeklindedir (Yıldırım ve Şimşek, 2011). İlk olarak nitel veriler ayrı ayrı kodlanmıştır. İlk kodlama süreci sonucunda kodlama güvenirliği \%85 olarak bulunmuştur. Hesaplama sonucundan Miles ve Huberma'nın (1994) belirttiği \%80 uyum düzeyinin üzerinden olduğu için kodlamanın güvenilir sonuç verdiği ifade edilebilir. Bu süreçte çalışmanın geçerliğini ve güvenirliğini arttırmak için (1) öğretmenlere uygulamalar öncesinde çalışma ile ilgili bilgilendirme yapılmış, (2) gönüllü olan öğretmenler sürece dahil edilmiş ve (3) öğretmenlere farklı rumuzlar verilerek bilgileri gizli tutulmuştur.

\section{Ders Planı Değerlendirme Ölçütlerinin Belirlenmesi: Geçerlilik ve Güvenirliği}

Öğretmenler ile yapılan görüşmeler sonucunda, ders planlarının değerlendirmesi için yedi ölçüt belirlenmiştir. $\mathrm{Bu}$ ölçütler belirlenirken, öğretmenlere "Bir ders planı oluştururken dikkat ettiğiniz noktalar nelerdir? sorusu sorulmuştur. Öğretmenlerin bu soruya verdikleri cevaplar araştırmacı ve bir uzman yardımı ile analiz edilmiştir. Analiz sonucunda yedi ölçüt belirlenmiştir. Bu ölçütlere ilişkin bilgiler Tablo 3'de verilmiştir.

Tablo 3. Ders Planlarının Değerlendirilmesinden Kullanılan Ölçüt ve Açıklamalarına İlişsin Bilgiler

\begin{tabular}{lll}
\hline Tema & Açılama \\
\hline $\begin{array}{l}\text { STEM Alanlarına Uygunluk } \\
\text { (SAU) }\end{array}$ & $\begin{array}{l}\text { Fen Bilimleri, Matematik, Mühendislik Bilgi ve becerileri ile Teknoloji } \\
\text { alanın entegrasyonunun birlikte kullanılmasını ifade etmektedir. }\end{array}$ \\
\hline $\begin{array}{l}\text { STEM Eğitimin } \\
\text { Uygunluk (SEDU) }\end{array}$ & Doğasına & $\begin{array}{l}\text { Fen Bilimleri, Matematik, Mühendislik Bilgi ve becerileri ile Teknoloji } \\
\text { entegrasyonun yapılması, bilgilerin günlük yaşamla ilişkili bir şekilde } \\
\text { verilerek gerçek bir dünya probleminin çözümüne imkan verilmesi, } \\
\text { mühendislik dizayn süreçlerini kapsıyor olması ve 21. yüzyıl becerilerini } \\
\text { geliştiren nitelikte olmasıdır. }\end{array}$ \\
\hline $\begin{array}{l}\text { Öğretme-Öğrenme } \\
\text { Uygunluk (ÖÖOSU) }\end{array}$ & 5Ërecingrenme modeli aşamalarına uygunluğu içermektedir. \\
\hline $\begin{array}{l}\text { Zaman Açısından Uygunluk } \\
\text { (ZAU) }\end{array}$ & $\begin{array}{l}\text { Ders planlarının belirtilen süreyi kapsayacak şekilde hazırlanmasını } \\
\text { içermektedir. }\end{array}$ \\
\hline $\begin{array}{l}\text { Sınıf Düzeyine Uygunluk } \\
\text { (SDU) }\end{array}$ & $\begin{array}{l}\text { Hazırlanan ders planlarının öğrencilerin yaş gruplarına uygunluğunu } \\
\text { ifade etmektedir. }\end{array}$ \\
\hline
\end{tabular}




\begin{tabular}{ll}
\hline Uygulanabilirlik (UY) & $\begin{array}{l}\text { Hazırlan ders planlarının sınıf düzeyine, öğrenci yaş grubuna ve alana } \\
\text { uygun olup sınıf ortamında uygulanabilir olmasını ifade etmektedir. }\end{array}$ \\
\hline $\begin{array}{l}\text { Günlük Yaşamla Bağlantıya } \\
\text { Uygunluk (GYBU) }\end{array}$ & $\begin{array}{l}\text { Hazırlanan ders planlarının günlük yaşamla bağlantılı olmasını ifade } \\
\text { etmektedir. }\end{array}$ \\
\hline
\end{tabular}

\section{Bulgular}

$\mathrm{Bu}$ bölümde dokümanların analizlerinden elde edilen bulgulara, öğretmenler ile yapılan görüşmelerden elde edilen bulgulara ve ders planı incelemelerine yönelik bulgulara yer verilmiştir.

\section{SÖEEM Modelinin Aşamalarına İlişkin Bulgular}

SÖEEM modelinin aşamalarının belirlenmesi için yapılan doküman analizi sonucunda kriterlere uygun olarak belirlenen çalışmalara Tablo 4'de yer verilmiştir.

Tablo 4. Doküman İncelemesi Sonucunda Elde Edilen Temalara İlişkin Bilgiler

\begin{tabular}{|c|c|c|c|c|c|c|c|c|c|}
\hline & Çalışmalar & SEO & İTE & $\mathrm{AB}$ & İS & EÖTE & DPO & $\mathrm{U}$ & $\mathrm{D}$ \\
\hline 1. & Aysal, (2005) & & $\checkmark$ & $\checkmark$ & $\checkmark$ & $\checkmark$ & & $\checkmark$ & $\checkmark$ \\
\hline 2. & Corlu, Capraro ve Capraro, (2014) & & & & $\checkmark$ & & & & \\
\hline 3. & Du vd. (2019) & & $\checkmark$ & $\checkmark$ & $\checkmark$ & & $\checkmark$ & $\checkmark$ & $\checkmark$ \\
\hline 4. & Eckman, Williams ve Silver-Thorn (2016) & & & & $\checkmark$ & & & & \\
\hline & Gencer, Doğan, Bilen ve Can, (2019) & & $\checkmark$ & & $\checkmark$ & & & & \\
\hline 6. & Goodnough, Pelech ve Stordy (2014) & & $\checkmark$ & & $\checkmark$ & & & $\checkmark$ & \\
\hline 7. & $\begin{array}{l}\text { Guzey, Tank, Wang, Roehring ve Moore, } \\
\text { (2014) }\end{array}$ & & & $\checkmark$ & $\checkmark$ & & & & \\
\hline 8. & Jho, Hong ve Song, (2016). & & & $\checkmark$ & $\checkmark$ & $\checkmark$ & & & \\
\hline 9. & Margot ve Kettler (2019) & & & & $\checkmark$ & & $\checkmark$ & $\checkmark$ & $\checkmark$ \\
\hline 10. & Miller-Bolotin, (2018) & & & & $\checkmark$ & & $\checkmark$ & $\checkmark$ & \\
\hline 11. & Nagdi, Leammukda ve Roehrig, (2018) & & $\checkmark$ & & $\checkmark$ & $\checkmark$ & & $\checkmark$ & \\
\hline 12. & Ring, Dare, Crotty ve Roehrig, (2017) & & & & $\checkmark$ & & $\checkmark$ & $\checkmark$ & $\checkmark$ \\
\hline 13. & $\begin{array}{l}\text { Rinke, Gladstone-Brown, Kinlaw ve } \\
\text { Cappiello, (2016) }\end{array}$ & $\checkmark$ & & & $\checkmark$ & & $\checkmark$ & $\checkmark$ & $\checkmark$ \\
\hline 14. & Stohlmann, Moore ve Roehrig, (2012) & & & & $\checkmark$ & & $\checkmark$ & $\checkmark$ & $\checkmark$ \\
\hline 15. & Türk, Kalaycı ve Yamak, (2018) & & & & $\checkmark$ & $\checkmark$ & $\checkmark$ & $\checkmark$ & \\
\hline 16. & Yıldırım ve Şahin-Topalcengiz, (2018) & & & & $\checkmark$ & & & & \\
\hline$\overline{17 .}$ & Yıldırım, (2018) & & $\checkmark$ & $\checkmark$ & $\checkmark$ & $\checkmark$ & $\checkmark$ & $\checkmark$ & $\checkmark$ \\
\hline
\end{tabular}

Tablo 4 incelendiğinde, SÖEEM modelinin aşamaları STEM Eğitim Okuryazarlığ (SEO), İhtiyaçların Tespit Edilmesi (ITTE), Amaçların Belirlenmesi (AB), İçeriğin Seçilmesi (İS), Eğitimcilerin ve Özelliklerinin Tespit Edilmesi (EÖTE), Ders Planı Oluşturma (DPO), Uygulama (U) ve Değerlendirme (D) olmak üzere sekiz farklı tema altında birleştiği tespit edilmiştir. Doküman analizi sonucunda belirlenen bu temalar, SÖEEM modelinin içeriğinin belirlenmesinde kullanılmıştır. Bu doğrultuda eğitim içerikleri oluşturulmuştur.

\section{Öğretmen Görüşlerine İlişkin Bulgular}

Öğretmenler ile yapılan görüşmeler sonucunda elde edilen nitel veriler içerik analizine tabi tutulmuştur. Elde edilen nitel veriler incelenerek Şekil 3'de verilen kod ve temalara ulaşılmıştır. 

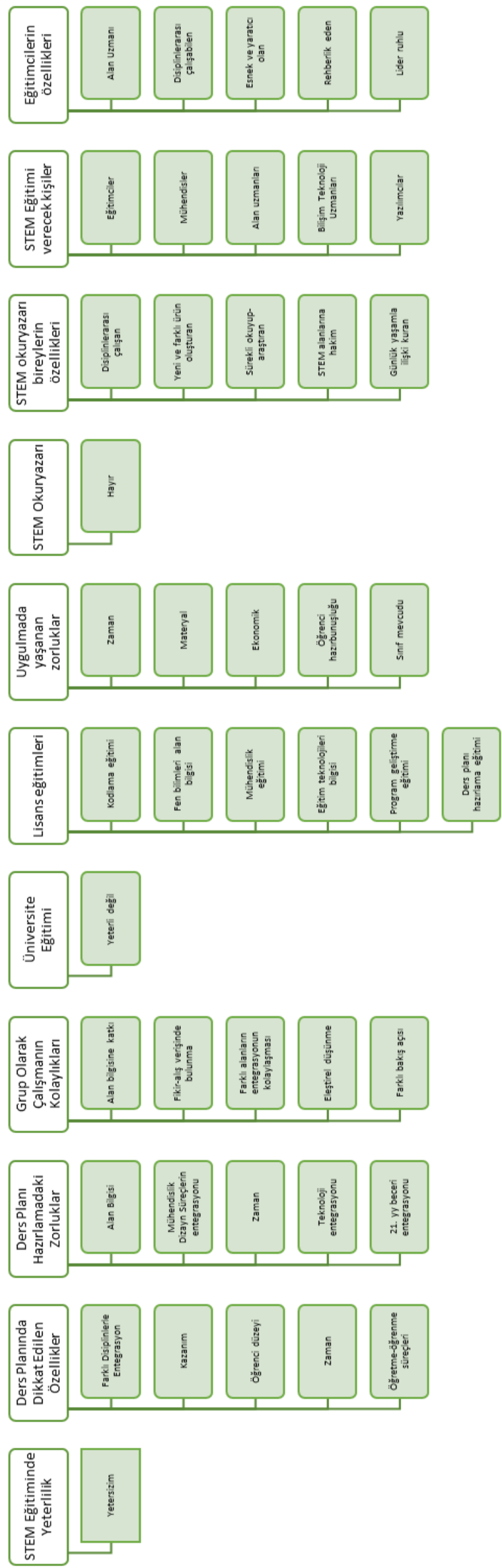
Şekil 3 incelendiğinde, öğretmenlerin görüşleri 11 farklı tema ile bu temaların altında yer alan 44 farklı koddan oluşmaktadır. Öğretmen görüşleri, STEM eğitimi yeterliliklerinden, STEM eğitimini verecek eğitimcilerin özelliklerine kadar birçok farklı tema hakkında bilgi içermektedir.

Şekil 3'de verilen STEM eğitiminde yeterlilik temas1 incelendiğinde, öğretmenler STEM eğitimi konusunda kendilerini yeterli hissetmediklerini düşünmektedir. Öğretmenler 1) mühendislik bilgisi, 2) matematik bilgisi, 3) kodlama bilgisi, 4) teknoloji bilgisi ve 5) program bilgisi ve ders planı hazırlama bilgisi açısından kendilerini yetersiz hissettiklerini ifade etmişlerdir. Bu temaya ilişkin örnek öğretmen görüşleri aşağıda verilmiştir. Bunlar:

G1: STEM eğitimini slnıfima uygularken alan bilgisi anlamında eksiklerimin olduğunu düşünüyorum. (STEM eğitiminde yeterlilik-yetersizim)

G2: Branşım fen bilimleri ĕgitimi olduğu için Teknoloji ve Mühendislik bilgisi konusunda eksik olduğumu söyleyebilirim. (STEM eğitiminde yeterlilik-yetersizim)

G3: Üniversitede mühendislik eğitimi almadı̆̆ımı için uygulamalar sırasında kendimizi yeterli hissetmiyoruz. (STEM eğitiminde yeterlilik-yetersizim)

Şekil 3'de verilen ders planında dikkat edilen özellikler teması incelendiğinde, öğretmenler, ders planı hazırlarken 1) farklı disiplinlerle entegrasyon, 2) kazanım, 3) öğrenci düzeyi, 4) zaman ve 5) öğretme-öğrenme süreçlerine dikkat ettiklerini ifade etmiştir. Bu temaya ilişkin örnek öğretmen görüşleri aşağıda verilmiştir. Bunlar:

G2: Ders planı kapsaminda belirlediğim konunun diğer alanlarla entegre edilip edilmeyeceğine dikkat ederek hareket ederim. (Ders planında dikkat edilen özellikler Farklı disiplinlerle entegrasyon)

G3: Ders planı hazırlarken kazanım seçerim ve o kazanma hizmet edecek giriş, gelişme ve sonuç bölümleri tasarlarım. (Ders planında dikkat edilen özellikler - Kazanım)

G9: Ders planı oluşturulurken yöntem ve tekniklerin seçimine dikkat ederim. (Ders planında dikkat edilen özellikler - Öğretme-öğrenme süreçleri)

Şekil 3'de verilen ders planı hazırlamadaki zorluklar teması incelendiğinde, öğretmenler ders planı hazırlarken 1) alan bilgisi, 2) mühendislik dizayn süreçlerinin entegrasyonu, 3) zaman, 4) teknoloji entegrasyonu ve 5) 21. yy becerileri konusunda zorluk yaşadıklarını ifade etmiştir. Bu temaya ilişkin örnek öğretmen görüşleri aşağıda verilmiştir. Bunlar:

G4: STEM planlarında dersler arası ilişkilendirmede zorluk yaşamaktayım. Çünkü alan bilgisi konusunda yeterli olmadığımı düşünüyorum. (Ders planı hazırlamadaki zorluklar - Alan Bilgisi)

G6: Ortaya çıkacak ürünü ve problem durumunu yazmakta biraz zorlanıyorum. (Ders planı hazırlamadaki zorluklar - Mühendisli dizayn süreçlerinin entegrasyonu)

G7: Yetiştirilmesi gereken bir müfredat olduğundan ders planı hazırlarken yeterli zamanı ayarlamada sorun yaşayabilirim. (Ders planı hazırlamadaki zorluklar - Zaman)

Şekil 3'de verilen öğretmenlere bireysel ders planı hazırlamanın mı yoksa grup olarak ders planı hazırlamanın $\mathrm{m} ı$ zor olduğu sorulmuştur. Öğretmenlerin tamamı grup olarak ders 
planı hazırlamanın daha kolay olduğunu vurgulamıştır. Bu noktada, grup olarak çalışmanın kolaylıkları teması incelendiğinde, öğretmenler, 1) alan bilgisine katk1, 2) fikir-alışverişinde bulunmayı sağlama, 3) farklı disiplinlerin entegrasyonun sağlanması 4) eleştirel düşünme ve 5) farklı bakış açısı kazandırmandan dolayı grup çalışmasının ders planı hazırlamayı kolaylaştırdığını ifade etmiştir. Bu temaya ilişkin örnek öğretmen görüşleri aşağıda verilmiştir. Bunlar:

G7: Bazen bizim göremediğimiz eksiklerimizi onlar bize göstermektedir. Bir araya gelerek birde sinerji oluşmaktadır. (Grup olarak çalışmanın kolaylıkları - Alan bilgisine katk1)

G8: Öğretmenlerle bir araya gelerek disiplinlerarası ders planı hazırlarken daha çok fikir ve farklı bakış açıları kazandırlldı̆̆ için daha kolay olabiliyor. (Grup olarak çalışmanın kolaylıkları - Farklı bakış açısı kazanma)

G9: Grup çalışmalarında ders planı oluşturulurken eleştirel bir şekilde çalışmalara bakıyoruz. (Grup olarak çalışmanın kolaylıkları - Eleştirel düşünme)

Şekil 3'de verilen üniversite eğitimi teması incelendiğinde, öğretmenler üniversitede verilen eğitimlerin STEM eğitimi için yeterli olmadığını vurgulamıştır. Öğretmenler ayrıca lisans eğitimlerinde verilen eğitimlere ilişkin görüşlerini de ifade etmiştir. Lisans eğitimleri teması incelendiğinde, öğretmenler özellikle 1) kodlama eğitimleri, 2) fen bilimleri alan bilgisi, 3) mühendislik eğitimi, 4) eğitim teknolojileri bilgisi ve 5) program ve ders planı geliştirmeye ilişkin bilgilerin verilmesi gerektiği üzerinde durmuştur. $\mathrm{Bu}$ temaya ilişkin örnek öğretmen görüşleri aşağıda verilmiştir. Bunlar:

G1: Hayır yeterli değildi. Günümüz teknolojine ayak uyduracak robotik ve kodlama eğitimi, STEM yaklaşımına uygun ĕgitimler... (Üniversite eğitimi - kodlama eğitimleri)

G2: Maalesef hayır, teknoloji ve mühendislik alanlarında oldukça eksiğim. Bu alanlarda ögretmenlik branşlarının eğitim alması gerektiğini düşünüyorum. (Üniversite eğitimi - mühendislik eğitimi)

G10: Eğitim alanında iyi bir üniversitede okudum ancak aldı̆̆ım eğitimin yeterli olduğunu düşünmüyorum. Özellikle eğitim fakültelerinde eğitim teknolojileri alanında derslerin olması gerektiğini düşünüyorum. (Üniversite eğitimi - eğitim teknolojileri bilgisi)

Şekil 3'de verilen uygulamada yaşanan zorluklar teması incelendiğinde, öğretmenler bu zorlukları 1) zaman, 2) materyal, 3) ekonomik, 4) öğrenci hazırbulunuşluğu ve 5) sinıf mevcudu olarak göstermiştir. Bu temaya ilişkin örnek öğretmen görüşleri aşağıda verilmiştir. Bunlar:

G1: Sinıfların kalabalık olması uygulamanın yapılmasını zorlaştırmaktadır. (Uygulamada yaşanan zorluklar - Sınıf mevcudu)

G2: Öğrencilerle ilgilenme noktasında zaman sorunları ile karşılaşılabilir. (Uygulamada yaşanan zorluklar - Zaman)

G8: Materyal temininde karşılaşılan maliyet sıkıntıları (Uygulamada yaşanan zorluklar - Ekonomik) 
Şekil 3'de verilen STEM okuryazarlığı teması incelendiğinde, öğretmenlerin tamamı kendilerini STEM okuryazarı olarak görmediklerini ifade etmiştir. Bunun üzerine öğretmenlere STEM okuryazarı bireyler nasıl olmalıdır sorusu sorulmuştur. Öğretmenler STEM okuryazarı bireyin 1) disiplinlerarası çalışan, 2) yeni ve farklı ürünler oluşturan, 3) sürekli okuyup araştıran, 4) STEM alanlarına hakim olan ve 5) öğrendiği bilgileri günlük yaşamıyla ilişkilendiren kişiler olarak tanımlamıştır. Bu temaya ilişkin örnek öğretmen görüşleri aşağıda verilmiştir. Bunlar:

G7: Öğrendiği teorik bilgileri hayatında uygulayan ve yeni bir şey üreten kişidir. (STEM okuryazarlığı - Hayır)

G9: Değilim. STEM okuryazarı birey sürekli okuyan, okuduğunu hayatına aktaran ve yeni ürünler ortaya çıkaran kişidir. (STEM okuryazarlığı - Hayır)

G10: Ben kendimi STEM okuryazarl birey olarak görmüyorum. Çünkü STEM okuryazarı olan bir kişi STEM alanlarına hakim, disiplinler arası çalışan bir kişidir. (STEM okuryazarlığı - Hayır)

Şekil 3'de verilen STEM eğitimini verecek kişiler teması incelendiğinde, öğretmenler STEM eğitimlerini 1) eğitimcilerin, 2) mühendislerin, 3) alan uzmanlarının 4) bilişim teknoloji uzmanlarının ve 5) yazılımcıların vermesi gerektiğini düşünmektedir. Bu temaya ilişkin örnek öğretmen görüşleri aşağıda verilmiştir. Bunlar:

G1: İyi bir şekilde algoritma bilen, kodlamaya hakim yazllım alanında görev yapan kişilerin eğitimler vermesi gerekmektedir. (STEM eğitimini verecek kişiler - Bilişim teknoloji uzmanları)

G5: STEM eğitimini sinıfta uygulana bilmesi için iyi bir pedagoji bilgisine ihtiyaç vardır. Bu sebepten eğitimi veren kişiler arasında eğitim alanında çalışan kişilerinde olması gerekmektedir. (STEM eğitimini verecek kişiler - Eğitimciler)

G7: Mühendislik alanını en iyi mühendisler bildiği için mühendislerinde eğitimler vermesi gerekmektedir. (STEM eğitimini verecek kişiler - Mühendisler)

Şekil 3'de verilen eğitimcilerin özellikleri teması incelendiğinde, öğretmenler eğitimcilerin 1) alan uzmanı, 2) disiplinlerarası çalışan, 3) esnek ve yaratıcı, 4) rehberlik eden ve 5) lider ruhlu kişiler olması gerektiğini ifade etmiştir. Bu temaya ilişkin örnek öğretmen görüşleri aşağıda verilmiştir. Bunlar:

G2: STEM eğitimini iyi bilen ve bu alana hakim kişilerin olması gerekmektedir. (Eğitimcilerin özellikleri - Alan uzmanı)

G3: STEM eğitimini veren kişilerin insanların yolunu aydınlatan ve onlara yol gösteren bir kişiliğinin olması germektedir. (Eğitimcilerin özellikleri - Lider ruhlu)

G7: STEM eğitimleri sırasında yapılan mühendislik uygulamalarına rehberlik etmesi gerekir. (Eğitimcilerin özellikleri - Rehberlik eden)

\section{Ders Planlarının İncelenmesine İlişkin Bulgular}

Öğretmenlerin hazırlamış oldukları ders planları SAU, SEDU, ÖÖEU, ZAU, SDU, UY ve GYDB temaları altında ayrıntılı şekilde incelenmiştir (Bkz. Tablo 2). 
Tablo 5. Bireysel Ders Planlarının SAU'ya İlişsin Bilgileri

\begin{tabular}{llc}
\hline Tema & Kodlar & $\mathrm{f}$ \\
\hline SAU & Uygun & 9 \\
& Uygun değil & 31 \\
\hline
\end{tabular}

Tablo 5 incelendiğinde, hazırlanan ders planlarından dokuz tanesinde dört temel alan ve daha fazlası kullanılırken 31 ders planında ise, en fazla üç alanın birlikte kullanıldığı tespit edilmiştir. En fazla üç alanın yer verildiği 31 ders planında yer verilmeyen alanlara ilişkin bilgiler Tablo 6' da verilmiştir.

Tablo 6. Bireysel Ders Planlarında Yer Verilmeyen Alanlara İlişsin Bilgileri

\begin{tabular}{llc}
\hline Tema & Kodlar & $\mathrm{f}$ \\
\hline Yer verilmeyen alanlar & Matematik & 18 \\
& Mühendislik beceri ve kavramları & 16 \\
& Fen Bilimleri & 11 \\
\hline
\end{tabular}

*Bazı ders planlarında iki ve daha fazla alan entegre edilmemiştir.

Tablo 6 incelendiğinde, bireysel hazırlanan ders planlarında özellikle STEM alanlarından matematik, mühendislik beceri ve kavramları ile fen bilimleri alanlarının eksik olduğu tespit edilmiştir. STEM alanlarına uygunluğun yanında ders planlarının incelemesinde farklı özelliklere de bakılmıştır. Bu özelliklere ilişkin elde edilen bulgular Tablo 7'de verilmiştir.

Tablo 7. Bireysel Hazırlanan STEM Ders Planlarında Aranan Özelliklere İliş̧kin Bilgileri

\begin{tabular}{lll}
\hline Tema & Kodlar & f \\
\hline SEDU & Uygun & 9 \\
& Uygun değil & 31 \\
\hline ÖÖSU & Uygun & 37 \\
& Uygun değil & 3 \\
\hline ZAU & Uygun & 33 \\
& Uygun değil & 7 \\
\hline SDU & Uygun & 39 \\
& Uygun değil & 1 \\
\hline UY & Uygun & 39 \\
& Uygun değil & 1 \\
\hline GYBU & Uygun & 40 \\
& Uygun değil & - \\
\hline
\end{tabular}

Tablo 7 incelendiğinde, öğretmenlerin yapmış oldukları ders planları farklı özelliklere göre değerlendirilmiştir. Öğretmenlerin hazırlamış oldukları ders planlarının çoğunluğunun öğretmen-öğrenme sürecine, zamana, sınıf düzeyine uygun ve uygulanabilir olduğu anlaşılmaktadır. Dahası, ders planlarının tamamının günlük yaşamla bağlantı kurularak yazıldığı ancak hazırlanan ders planlarının çoğunun STEM eğitiminin doğasını yansıtmadığı da tespit edilmiştir. Tablo 6'da yer alan tema ve kodlara ilişkin ders planlarından örnek cevaplar aşağıda belirtilmiştir. Bunlar:

G1: Matematik dersi kapsaminda verilen "Veri Düzenleme ve Yorumlama" ve Fen Bilimleri dersi ile ilgili olarak "Evsel Atıklar ve Geri Dönüşüm” konusunun öğretilmesi, Geri dönüşümü mümkün olan malzemeler ile yeni ve farkl tasarımın gerçekleştirilmesi ve Teknoloji ile ilgili video, bilgisayar gibi teknolojik araçlarının entegre edilmesi. 
Kazandırılmak istenen "İşbirliği, Problem Çözme, Eleştirel Düşünme” becerilerinin geliştirilmesini kapsamaktadır. (SEDU - uygun)

G4: Fen Bilimleri kapsamında sürtünme kuvvetinin öğretilmesi, tasarım olarak farklı yüzey alanlarının kullanılarak sürtünmenin cisimler üzerinde etkisinin ögretilmesini să̆lamak içeren ders planı. (SEDU - uygun değildir. Çünkü, Matematik alan bilgisinin nasıl entegre edildiğinin verilmemesi, kazandırılması gereken 21. Yy becerilerini içermemesi)

G5: Hazırlanan ders planında 5E öğrenme modelin tüm aşamalarının doğru şekil verilmesi. (ÖÖSU - uygun)

G6: Ders planında Giriş, Keşfetme, Açılama ve Derinleştirme kısmı yer alırken Değerlendirme kismının yer almamast. (ÖÖSU - uygun değil)

G4: Enerji Dönüşümleri konusunun ögretilmesi, Matematikte oran-orantı konusunun ögretilmesi, enerji türlerinin birbirine dönüştüğ̈̈nü açıklamak için yeni bir tasarımın yaptırllması ders planın planlanmıştır. Ancak Ders saat süresi 4 ders saati olarak belirlenmiştir. (ZAU - uygun değil)

G7: Sıvıların sıkıştırılamaz özelliğinin öğretilmesi, geometrik şekillerin öğretilmesi ve bir roket tasarımının yaptırılarak roket rampasıyla firlatılması (SDU - Okulöncesi öğretmenliğine uygun değildir; UY- uygun değil)

G8: Hazırlanan ders planinda "Günlük yaşamdan evsel atıklara örnekler verilmesi, Su arıtma sistemleri ile ilgili videonun izletilmesi” gibi örneklerin yer almast. (GYBU - Uygun)

Tablo 8. Grup olarak Hazırlanan Ders Planlarının SAU'ya İlişsin Bilgileri

\begin{tabular}{lll}
\hline Tema & Kodlar & f \\
\hline SAU & Uygun & 4 \\
& Uygun değil & 6 \\
\hline
\end{tabular}

Tablo 8 incelendiğinde, grup olarak hazırlanan ders planlarından dört tanesinde en az dört alanın entegre edilerek verildiği ancak diğer ders planlarında en fazla üç alanın entegre edildiği tespit edilmiştir. Grup bazında yer verilmeyen alanlara ilişkin bilgiler ise Tablo 9'da verilmiştir.

Tablo 9. Grup olarak Hazırlanan Ders Planlarında Yer Verilmeyen Alanlara İlişkin Bilgileri

\begin{tabular}{|c|c|c|c|}
\hline Gruplar & Tema & Kodlar & f \\
\hline Okulöncesi öğretmen grubu 1 & \multirow{6}{*}{ 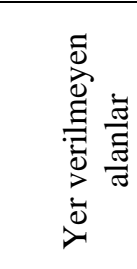 } & Fen Bilimleri & 1 \\
\hline Okulöncesi öğretmen grubu 2 & & Matematik, Mühendislik beceri ve kavramları & 1 \\
\hline Sınıf Öğretmen grubu & & Mühendislik beceri ve kavramları & 1 \\
\hline Fen Bilimleri Öğretmen grubu & & Mühendislik beceri ve kavramları & 1 \\
\hline Matematik Öğretmen grubu & & Fen Bilimleri & 1 \\
\hline Teknoloji Tasarım öğretmen grubu & & Fen Bilimleri ve Matematik & 1 \\
\hline
\end{tabular}

Tablo 9 incelendiğinde, oluşturulan grupların hazırladıkları ders planlarında branşı bazında farklılıklar görüldüğ̈̈ anlaşılmaktadır. Grup olarak hazırlanan ders planlarında fen 
bilimleri, matematik, mühendislik beceri ve kavramları konusunda eksikliklerin olduğu anlaşılmaktadır.

Tablo 10. Grup olarak Hazırlanan STEM Ders Planlarında Aranan Özelliklere İliş̧kin Bilgileri

\begin{tabular}{llc}
\hline Tema & Kodlar & $\mathrm{f}$ \\
\hline SEDU & Uygun & 4 \\
& Uygun değil & 6 \\
\hline ÖÖSU & Uygun & 10 \\
& Uygun değil & - \\
\hline ZAU & Uygun & 10 \\
& Uygun değil & - \\
\hline SDU & Uygun & 10 \\
& Uygun değil & - \\
\hline \multirow{2}{*}{ UY } & Uygun & 10 \\
& Uygun değil & - \\
\hline GYBU & Uygun & 10 \\
& Uygun değil & - \\
\hline
\end{tabular}

Tablo 10 incelendiğinde, grup olarak hazırlanan ders planlarının tamamının öğretmeöğrenme süreçlerine, zamana ve sınıf düzeyine uygun olarak hazırlandığı ve günlük yaşamla bağlantılı kurulduğu tespit edilmiştir. Bu ders planlarının tamamının ise, uygulanabilir nitelikte olduğu söylenebilir. Bunun yanında hazırlanan ders planlarının çoğunun STEM eğitiminin doğasına uygun olarak hazırlanmadığı da anlaşılmaktadır.

\section{Tartışma ve Sonuç}

$\mathrm{Bu}$ çalışmada, STEM eğitimiyle ilgili olarak öğretmenlerin mesleki gelişmelerini sağlamak amacıyla bir öğretim modeli önerisinde bulunulmuştur. Bu amaç doğrultusunda, ilk olarak SÖEEM modelinin aşamaları doküman analiziyle belirlenmiştir. Aşamalar belirlendikten sonra öğretmenlere eğitimler verilmiş ve ders planı oluşturulmuştur. Oluşturulan ders planları belirlenen özellikler doğrultusunda analiz edilmiş ve öğretmenlerin görüşleri alınmıştır.

Çalışma kapsamında elde edilen ilk bulgu, doküman analizleri sonuçlarına ilişkindir. Doküman analizleri sonucunda, öğretmenlerin STEM mesleki gelişimlerini sağlamak için STEM eğitim okuryazarlığı, ihtiyaçların tespit edilmesi, amaçların belirlenmesi, içerik seçimi, eğitimciler ve özelliklerinin belirlenmesi, ders planı oluşturma, uygulama ve değerlendirme aşamalarının olması gerektiği üzerinde durulmuştur. Alanyazın incelendiğinde, bu çalışmada elde edilen sonuçlarla paralellik gösteren çalışmalara rastlanmıştır (Du vd., 2019; Gencer, Doğan, Bilen ve Can, 2019; Guzey vd., 2014; Jho, Hong ve Song, 2016; Rinke, GladstoneBrown, Kinlaw ve Cappiello, 2016; Stohlmann, Moore ve Roehrig, 2012; Türk, Kalayc1 ve Yamak, 2018; Yıldırım, 2018; Yıldırım ve Şahin-Topalcengiz, 2018). Eckman, Williams ve Silver-Thorn (2016) çalışmasında, STEM eğitiminde içerik seçimine vurgu yaparken Nagid, Leammukda ve Roehrig (2018) çalışmasında ihtiyaçlarının belirlenmesi, uygun içeriğin seçilmesi, eğitimi verecek uzmanların belirlenmesi ve uygulama yapılmasının önemini üzerine vurgu yapmıştır. Benzer şekilde, Goodnough, Pelech ve Stordy (2014) çalışmasında, STEM eğitimlerinin verileceği öğretmenlerin ihtiyaçlarının tespit edilmesi gerektiğini, öğretmenlerin özelliklerine göre içeriklerin belirlenmesinin önemli olduğunu ve uygulama yapılması gerektiği ifade etmiştir. Margot ve Kettler (2019) ise, STEM eğitimlerinde içerik seçilmesinin yanında STEM eğitimine uygun ders planı oluşturmanın, oluşturulan ders planının uygulanması ve 
değerlendirilmesi gerektiğini de vurgulamıştır. Elde edilen bu sonuçlar bu çalışma ile paralellik göstermektedir. Bunların yanında, Aysal (2005) köy enstitüleri üzerine yaptığı çalışmada, köy enstitüleri oluşturulurken ihtiyaçların tespit edilmesi, eğitimcilerin ve özelliklerinin belirlenmesi gibi farklı özellikler dikkate alındığını görülmektedir. Nitekim, Köy enstitülerinde eğitimi veren kişilerin farklı branşlardan olması öğretmenlerin farklı alanlarda bilgi kazanmalarını sağlamaktadır. Köy enstitülerinin bu özellikleri ile STEM eğitimlerinde farklı kişilerin eğitimler vermesinin ne kadar önemli olduğunu açıklamaktadır. Diğer bir deyişle, Aysal (2005)'in çalışmasından vurguladığı birçok özelliğin bu çalışma kapsamında belirlenen özellikler ile paralellik gösterdiği ifade edilebilir. Nitekim, Köy Enstitüleri hem köyün öğretmen ihtiyaçlarını karşılamak hem de köyün kalkınmasını sağlamak için kurulurken SÖEEM modelinin önerilmesi benzer sebeplere dayanmaktadır. Bu modelde 21. yüzyıl eğitim anlayışı ile donanımlı öğretmen ihtiyacını karşılamak hem de toplumun her yönüyle kalkınmasına katkı sağlamak yer almaktadır. Bu nedenle, bu çalışmada elde edilen sonuçlar ile alanyazında elde edilen sonuçlar birbirini desteklediği söylenebilir.

Çalışma kapsamında elde edilen ikinci bulgu, öğretmen görüşlerine ilişkindir. $\mathrm{Bu}$ kapsamda öğretmenler STEM eğitimi konusunda kendilerinin yeterli hissetmediklerini ifade etmiştir. Öğretmenler özellikle lisans eğitimlerinin yeterli olmadığını vurgulamıştır. Öğretmenler lisans eğitimlerinde kodlama eğitimleri, fen bilimleri, mühendislik, eğitim teknolojileri, program geliştirme ve ders planı hazırlama eğitimlerinin verilmesi gerektiği üzerinde durmuştur. Alanyazın incelendiğinde, öğretmen eğitimlerinde STEM alan ve pedagoji bilgisinin önemli bir yerinin olduğu vurgulanmaktadır (Kennedy, Ahn ve Choi, 2008; Murphy ve Mancini-Samuelson, 2012; Wang vd., 2011). Felix ve Harris (2010) STEM eğitimini verecek öğretmenlerin iyi bir alan ve pedagoji bilgisine sahip olması gerektiğini dile getirmiştir. $\mathrm{Bu}$ çalışmada elde edilen sonuçlar bu çalışmanın sonucu ile paralellik göstermektedir. Nitekim, alanyazın incelendiğinde, STEM eğitimi verecek olan öğretmenlerin STEM pedagoji alan bilgisine sahip olması gerektiği de vurgulanmaktadır (Cantrell, Pakca ve Ahmad, 2006; Haynes ve Santos, 2007; Ostler, 2012; Stohlmann, Moore ve Roehrig, 2012). STEM pedagojik alan bilgisi, öğretmenlerin STEM eğitimiyle ilgili sahip olması gereken alan bilgisi, bağlam bilgisi, pedagoji bilgisi, 21. yy beceri bilgisi ve entegrasyon bilgisine sahip olmayı içermektedir (Yıldırım, 2017). Nitekim, Yıldırım ve Şahin-Topalcengiz (2019) STEM pedagojik alan bilgisinin öğretmen eğitimi için önemli olduğu üzerinde durmuştur. Nitekim, alanyazında elde edilen bu sonuçlar ile bu çalışmanın sonuçları paralellik göstermektedir.

İkinci bulgu kapsamında elde edilen bir diğer sonuç ise, ders planı hazırlanırken dikkat edilen özelliklere ilişkindir. Öğretmenler ders planı hazırlarken farklı disiplinlerin entegrasyonu, öğretim programında yer alan kazanımlar, öğrenci düzeyine uygunluk, zaman ve öğretmeöğrenme süreçlerine dikkat ettiklerini ifade etmiştir. Bunun yanında ders planı hazırlarken öğretmenler alan bilgisi, mühendislik dizayn süreçlerinin entegrasyonu, zaman, teknoloji ve 21 . yy becerilerinin entegrasyonu konusunda sorun yaşadıklarını ifade etmiştir. Ayrıca, öğretmenler grup olarak ders planı hazırlamanın bireysel ders planı hazırlamaya oranla daha kolay olduğunu ifade etmiştir. Nitekim, Atik Kara ve Sağlam (2014) çalışmasında, öğretmenlerin ders planı oluştururken farklı özelliklere dikkat ettiklerini vurgulamaktadır. Bu çalışmada, araştırmacılar öğretmenlerin bir ders planı hazırlarken özellikle zamana, kazanımlara ve öğretim-yöntem tekniklere uygunluğa bakarak ders planı hazırladıklarını tespit etmiştir. Elde edilen bu sonuçlar bu çalışma ile paralellik göstermektedir. 
$\mathrm{Bu}$ kapsamda elde edilen diğer bir sonuç ise, STEM uygulamaları sırasında öğretmenlerin karşılaştıkları problemlere ilişkindir. Öğretmenler zamanın, materyal eksikliğinin, öğrenci hazırbulunuşluğunun istenilen düzeyde olmaması ve sınıf mevcutlarının yüksek olmasından dolayı uygulamalarda problem yaşadıklarını ifade etmiştir. Nitekim, alanyazında elde edilen sonuçlar bu çalışmada elde edilen sonuçları destekler niteliktedir ve STEM eğitimleri sırasında öğretmenlerin problemler yaşadığı vurgulanmaktadır (Jho vd., 2016; Yıldırım, 2018a). Özellikle, öğretmenler okullarda STEM eğitimlerini uygulamak için gerekli olan eğitim materyallerinin eksik olması ve uygulamaları yapmak için zamanın yetersiz olmasından dolayı problem yaşamaktadır (Lee ve Shin, 2014; Shin ve Han, 2011). Alanyazında elde edilen bu sonuçlar bu çalışmada elde edilen sonuçları destekler niteliktedir. Wang, Moore, Roehring ve Park (2011) ise, STEM eğitimleri sırasında yaşanan problemleri açılarken tüm öğretmen ve öğrencilere yönelik bir STEM eğitim programın olmamasının STEM eğitiminin doğru uygulanması önünde bir engel olduğunu ifade etmiştir. Elde edilen bu sonuçlar bu çalışmanın sonuçları ile paralellik göstermektedir.

$\mathrm{Bu}$ kapsamda elde edilen diğer bir sonuçta ise, öğretmenlerin grup halinde çalışmaya yönelik görüşlerine ilişkindir. Öğretmenler grup olarak çalışmanın alan bilgisi, fikir alışverişinde bulunma, farklı alanların entegrasyonu sağlamada kolaylık sağladığını ifade etmiştir. Örneğin; Jones ve Carter (2007) öğretmenlerin mesleki gelişimlerini sağlamak için grup çalışmasının hayati bir önemi olduğunu ifade etmektedir. Elde edilen bu sonuç ile paralellik göstermektedir. Benzer şekilde, öğretmenlerin beraber çalışmasının önemli olduğunu vurgulayan ve bu çalışmanın sonucunu destekleyen birçok çalışmaya da rastlanmıştır (Lee vd., 2013; Mak ve Pun, 2015; Noh ve Paik, 2014). Alanyazında elde edilen bu sonuçlar bu çalışmada elde edilen sonuçları destekler niteliktedir.

İkinci bulgu kapsamında elde edilen sonuncu sonuçta ise, öğretmenlerin tamamı STEM okuryazarı birey olmadıklarını ifade etmiştir. Nitekim, Bülbül ve Sözbilir'e (2017) göre, STEM okuryazarlığı, STEM eğitiminin öğrencilere öğretilmesi için gerekli olan bilgiye sahip olmayı ifade etmektedir. Bu çalışma kapsamında elde edilen bu sonuç, öğretmenlerin STEM eğitimlerini almadan önce STEM okuryazarı olmadıklarının farkına vardıkları şeklinde yorumlanabilir. Ayrıca, öğretmenler STEM okuryazarı bireyleri disiplinlerarası çalışan, yeni ve farklı ürünler ortaya koyan, sürekli okuyan, STEM alanlarına hakim olan kişiler olarak tanımlamıştır. Bunun yanında, Öğretmenler STEM eğitimlerini ise, eğitimcilerin, alan uzmanlarının, mühendislerin ve yazılımcıların vermesi gerektiği üzerinde durmuştur. Dahası, öğretmenler STEM eğitimlerini verecek olan kişilerin alan uzmanı, disiplinlerarası çalışan, esnek ve yaratıcı, rehberlik eden ve lider ruhlu kişiler olması gerektiğini vurgulamıştır.

Çalışma kapsamında elde edilen üçüncü bulguda ise, ders planlarının analizlerine ilişkindir. Öğretmenlerin bireysel olarak hazırladıkları ders planların çoğunluğunun STEM alanlarının tamamını kapsamadığı tespit edilmiştir. Bu ders planlarında matematik, mühendislik ve fen bilimleri alanlarının entegrasyonu konusunda sorunlar yaşandığı anlaşılmaktadır. Ayrıca öğretmenlerin hazırladıkları ders planlarının çoğunluğunun STEM eğitiminin doğasına uygun olmadığı ancak hazırlanan ders planlarının çoğunun öğretme-öğrenme süreci, zaman, sınıf düzeyi, uygulanabilirlik ve günlük yaşamla bağlantılı olduğu tespit edilmiştir. Bireysel olarak hazırlanan ders planlarında elde edilen sonuçlara paralel sonuçlar öğretmenlerin gruplar halinde yaptıkları ders planlarında da tespit edilmiştir. 
$\mathrm{Bu}$ bağlamda, doküman analizleri, öğretmen görüşleri ve ders planı incelemeleri sonucunda, öğretmenlerin STEM eğitimi mesleki gelişimlerini sağlamak için hazırlanan SÖEEM modelinin aşamaları oluşturulmuştur.

Bu aşamalar:

$\checkmark$ STEM eğitim okuryazarlığı

$\checkmark$ İhtiyaçların tespit edilmesi

$\checkmark$ Amaçların belirlenmesi

$\checkmark$ İçerik seçimi

$\checkmark$ Eğitimciler ve özelliklerinin belirlenmesi

$\checkmark$ Ders planı oluşturma

$\checkmark$ Uygulama

$\checkmark$ Değerlendirme

STEM okuryazarlığı: bireylerin 21. yüzyıl becerilerini geliştirmeleri, yaşam boyu öğrenen bireyler olmaları, disiplinlerarası çalışmaları, öğrendikleri bilgileri günlük yaşamlarına uygulayarak her alanda kendi gelişimlerini sağlamları için gerekli STEM eğitimiyle ilgili bilgi, beceri, tutum ve anlayışın bir birleşimidir. STEM okuryazarı olan öğretmenlerin STEM eğitimiyle ilgili olarak sürekli okuma yapması, güncel durumları takip etmesi, doğru kaynağa ulaşması ve öğrendiği bilgiler ile birleştirmesini içermektedir.

İhtiyaçların tespit edilmesi: bu aşama, eğitim alacak öğretmen grubunun branşlarının tespit edilmesi, alan, pedagoji, bağlam, entegrasyon ve 21. yy beceri bilgisi eksiklerinin tespit edilerek öğretmenler için gerekli ihtiyaçların tespit edilmesini kapsamaktadır. Bu aşama, branş bazında verilecek olan STEM eğitim içeriğinin belirlenmesine etki edecektir. Nitekim, Tablo 8 incelendiğinde, aynı branşta yer alan öğretmenlerin oluşturduklanı ders planlarında alan bilgisi eksiklerinin farklılık gösterdiği anlaşılmaktadır. Örneğin; okulöncesi öğretmenlerinin hazırladıkları ders planlarında fen bilimleri, matematik, mühendislik beceri ve kavramlarına ilişkin eksikleri yer alırken matematik öğretmenlerinin ise, fen bilimleri alan bilgisinde eksiklerin olduğu anlaşılmaktadır.

Amaçların belirlenmesi: STEM eğitimi mesleki gelişim programı ile öğretmenlere kazandırılması istenen bilişsel, duyuşsal ve psiko-motor hedeflerin belirlenmesini içermektedir. Örneğin, Mühendislik dizayn süreçlerini bilmek ve günlük yaşamında uygulamak gibi hedeflerin belirlenmesini içermektedir.

İçeriklerin belirlenmesi: Öğretmenlere verilecek olan STEM eğitim içeriklerinin tespit edilmesini içermektedir. Bu aşama, öğretmenlere STEM pedagojik alan bilgisinin [STEM PAB] verildiği aşamadır. STEM pedagojik alan bilgisi, STEM öğretmenlerinin sahip olması gereken bilgiyi içermektedir. STEM pedagojik alan bilgisi, alan bilgisi, pedagoji bilgisi, entegrasyon bilgisi, 21. yy beceri bilgisi ve bağlam bilgisini içermektedir (Yıldırım, 2017; Yıldırım ve Şahin-Topalcengiz, 2019). Öğretmenlerin görüşleri ve ders planları incelendiğinde, öğretmenlerin alan bilgisi, pedagoji bilgisi ve entegrasyon bilgisi konusunda eksiklerinin oldu 
anlaşılmaktadır. $\mathrm{Bu}$ yüzden öğretmenlere verilecek mesleki gelişim programında içeriklerin belirlenmesi ve eğitimlerin bu içerikler doğrultusunda verilmesi önemlidir.

Eğitimciler ve özelliklerinin belirlenmesi: Ulusal Bilim Kurumu'nun (UBK) (National Science Foundation [NSF]) (2014) tanımladığı STEM alanları içerisinde Sosyal Bilimlerden Matematik'e kadar farklı birçok alanın yer aldığı anlaşılmaktadır. Bu alanların doğasının ve bilgi yapısının farklılık göstermesi bu alanda çalışan uzmanlar ile bir araya gelip ortak çalışmalar yapılmasını gerekli kılmaktadır (Lee, Park ve Kim, 2013). Bu durum STEM eğitiminde kullanılacak alanların çok geniş olacağı anlamına gelmektedir. Bu alanların hepsine aynı anda derinlemesine hakim olmakta zor olduğu düşünüldüğünde, STEM eğitimlerini verecek kişilerin belirlenmesi önemlidir. Nitekim, Köylerin öğretmen ihtiyacını karşılamak ve kalkınmasını sağlamak için kurulan Köy Enstitülerinde, eğitimleri farklı branşlarda uzman kişiler vermektedir (Tonguç, 1947). STEM eğitimi de disiplinlerarası bir yaklaşım olduğu için farklı alanları kapsamaktadır. Bu nedenle eğitim verecek kişilerin farklı alanlarda uzman kişilerden oluşması gerekmektedir. Benzer şekilde, Yıldırım (2018b) STEM eğitimiyle ilgili yazdığı raporda, STEM eğitimlerine farklı fakültelerde görev yapan kişilerinde girmesi gerektiğini ve eğitimleri veren kişilerin ise, alanında uzman kişileri olması gerektiğini vurgulamıştır.

Ders planı oluşturma: bu aşama öğretmenlerin öğretim programına uygun olarak ders planı geliştirmelerini içermektedir. Bu sebepten, uygulama sırasında yapılacak etkinliklerin planlandığı aşama olması açısından önem arz etmektedir.

Uygulama: STEM eğitimlerinin sınıf içinde uygulanmasını ifade etmektedir. Öğretmenler sınıf içinde gerçekleştirecekleri STEM eğitimi uygulamalarıyla eğitimlerin aksayan ve eksik yanlarının neler olduğunu tespit etme fırsatı bulacaktır. Bu sayede, eğitimlerini baştan dizayn edebilecektir.

Değerlendirme: Verilen eğitimin bilişsel, duyuşsal ve psiko-motor çıtıları göz önüne alınarak değerlendirilmesini kapsamaktadır. Değerlendirme sonucunda STEM mesleki gelişim programında işlemeyen ve aksayan noktalar gözden geçirilir. Burada özellikle sonuç ve süreç odaklı değerlendirme yapılmasına özen gösterilmesi hem sürecin hem de sonuçların değerlendirilmesi açısından önemlidir.

\section{Öneriler}

Öğretmenlerin STEM eğitimi konusunda mesleki gelişimlerini sağlamak üzere geliştirilen SÖEMM modeli öğretmen eğitimlerinde kullanılabilir ve bu modelden yola çıkarak yeni modellerin geliştirilmesi sağlanabilir.

STEM eğitimi mesleki gelişim programlarında, SÖEEM modelinin aşamalarının kullanılabilir ve eğitimlerin bu aşamalara uygun olarak tasarlanıp verilmesi STEM eğitimlerinin ortak bir mesleki gelişim programına oturmasını sağlanabilir.

SÖEEM modeline uygun olarak öğretmenlere eğitimler verilecek öğretmenlerin farklı sınıf düzeylerine uygun ders planı hazırlamaları sağlanabilir ve hazırlanan bu ders planlarının sinıf ortamında uygulanmasina imkan verebilir.

SÖEMM modelinde belirtilen aşamalara uygun olarak öğretmen eğitimleri planlanabilir ve tüm branşlara uygun olarak eğitim sürecinin tasarlanması gerçekleştirilebilir. 


\section{Kaynakça}

Akgündüz, D. (2016). STEM'i rahat bırakın: Türkiye'de STEM adına yapılan hatalar ve öneriler. [Çevrim-içi: $\quad$ https://www.egitimpedia.com/stemi-rahat-birakin-turkiyede-stem-adina-yapilanhatalar-ve-oneriler/], Erişim tarihi: 19.12.2019.

Atik Kara, D., \& Sağlam, M. (2014). Öğretmenlik meslek bilgisi derslerinin öğrenme-öğretme sürecine yönelik yeterliklerinin kazandırılması yönünden değerlendirilmesi. Eğitimde Nitel Araştırmalar Dergisi - Journal of Qualitative Resarch in Education, 2(3), 28-86. doi: https://doi.org/10.14689/issn.2148-2624.1.2c3s2m

Aysal, N. (2005). Anadolu'da aydınlanma hareketinin doğuşu: köy enstitüleri. Ankara Üniversitesi Türk İnkılâp Tarihi Enstitüsü Atatürk Yolu Dergi, 35-36, 267-282.

Balcı, A. (2016). Sosyal bilimlerde araştırma yöntem teknik ve ilkeleri. Ankara: Pegem Akademi Yayınc1lik

Braga, J. L. (1972). Teacher role perception. Journal of Teacher Education, 23(1), 53-57.

Bülbül, M.Ş., \& Sözbilir, M. (2017). Engelsiz STEM eğitimi. Salih Çepni (Ed.). Kuramdan uygulamaya STEM+A+E eğitimi içinde (s. 511-531). Ankara: Pegem Akademi.

Cantrell, P., Pekca, G., \& Ahmad, I. (2006). The effects of engineering modules on student learning in middle school science classrooms. Journal of Engineering Education, 95(4), 301-309. https://doi.org/10.1002/j.2168-9830.2006.tb00905.x

Can, K., \& Uluçınar-Sağır, Ş. (2018). Sınıf öğretmenlerinin fen, teknoloji, matematik ve mühendislik (fetemm) uygulamalarina ilişkin görüşleri. Uluslararasi Türk Eğitim Bilimleri Dergisi, 6(11), 6283.

Çakır, Z., Yalçın, S. A., \& Yalçın, P. (2019). Montessori yaklaşımı temelli STEM etkinliklerinin okul öncesi öğretmen adaylarının yaratıc1lık becerilerine etkisi. Journal of the International Scientific Research, 4(2), 392-409. https://doi.org/10.21733/ibad.548456

Çepni, S., \& Ormancı, Ü. (2018). Geleceğin dünyası. S. Çepni (Eds.), Kuramdan uygulamaya STEM+A+E e ğitimi (pp. 1-37). Ankara: Pegem Yayıncılık.

Çevik, M., Danıştay, A., \& Yağcı, A. (2017). Ortaokul öğretmenlerinin FeTeMM (fen-teknolojimühendislik-matematik) farkındalıklarının farklı değişkenlere göre değerlendirilmesi. Sakarya University Journal of Education, 7(3), 584-599.

Çorlu, M. S., Capraro, R. M., \& Capraro, M. M. (2014). Introducing STEM education: implications for educating our teachers for the age of innovation. Eğitim ve Bilim, 39(171), 74 - 85.

Dass, P. M. (2001). Implementation of instructional innovations in K-8 science classes: Perspectives of in-service teachers. International Journal of Science Education, 23, 969-984. https://doi.org/10.1080/09500690010025021

Dick, W., \& Carey, L. (1996). The systematic design of instruction. USA: Harper Collins College Publishers.

Du, W., Liu, D., Johnson, C.C., Sondergeld, T. A., Bolshakova, V.L.J., \& Moore, T.J. (2019). The impact of integrated STEM professional development on teacher quality. School Science and Mathematics, 119, 105-114. https://doi.org/10.1111/ssm.12318

Ejiwale, J. (2013). Barriers to successful implementation of STEM education. Journal of Education and Learning, 7(2), 63-74. https://doi.org/10.11591/edulearn.v7i2.220

Felix, A., \& Harris, J. (2010). A project-based, STEM integrated: Alternative energy team challenge for teachers. The Technology Teacher, 69(5), 29-34.

Freeman, B. (2013). Science, mathematics, engineering and technology (STEM) in Australia: Practice, policy and programs. Melbourne: Australian Council of Learned Academies.

Gedikoğlu, Ş. (1971). Evreleri, getirdikleri ve yankilarıyla köy enstitüleri. Ankara: İdeal Matbaası.

Gencer, A. S., Doğan, H., Bilen, K., \& Can, B. (2019). Integrated STEM education models. Pamukkale Üniversitesi Eğitim Fakültesi Dergisi, 45, 38-55. 
Goodnough, K., Pelech, S., \& Stordy, M. (2014). Effective professional development in STEM education: the perceptions of primary/elementary teachers. Teacher Education and Practice, 27(2/3), 402424.

Gökdere, M., \& Çepni, S. (2003). Üstün yetenekli çocuklara verilen değerler eğitiminde öğretmenin rolü. Değerler Ë̆itimi Dergisi, 1(2), 93-107.

Guzey, S.S., Tank, K., Wang, H., Roehrig, G., \& Moore, T. (2014). A High-quality professional development for teachers of grades 3-6 for implementing engineering into classrooms. School Science and Mathematics, 114(3), 139-149. https://doi.org/10.1111/ssm.12061

Haynes, M.M., \& Santos, A.D. (2007). Effective teacher professional development: Middle school engineering content. International Journal of Engineering Education, 23(1), 24-29.

Hibpshman, T. L. (2007). Analysis of transcript data for mathematics and science teachers. Frankfort, Kentucky: Education Professional Standards Board.

Hossain, M. M., \& Robinson, M. G. (2012, March). How to overcome barriers and misconceptions of STEM education in the United States. In Society for Information Technology \& Teacher Education International Conference, 1, 3367-3372.

Jho, H., Hong, O., \& Song, J. (2016). An analysis of STEM/STEAM teacher education in Korea with a case study of two schools from a community of practice perspective. Eurasia Journal of Mathematics, Science \& Technology Education, 12(7), 1843-1862. https://doi.org/10.12973/eurasia.2016.1538a

Johnson, C. C., \& Fargo, J. D. (2010). Urban school reform enabled by transformative professional development: Impact on teacher change and student learning of science. Urban Education, 45(1), 4-29. https://doi.org/10.1177/0042085909352073

Jon, J. E., \& Chung, H. I. (2013). STEM report - republic of Korea. Melbourne: Australian Council of Learned Academies.

Jones, M. G., \& Carter, G. (2007). Science teacher attitudes and beliefs. In S. K. Abell \& N. G. Lederman (Eds.), Handbook of research on science education (pp. 1067-1104). Mahwah, NJ: Lawrence Erlbaum Associates.

Karakaya, F., Ünal, A., Çimen, O., \& Yilmaz, M. (2018). Fen bilimleri öğretmenlerinin stem yaklaşimina yönelik farkindaliklari. Eğitim ve Toplum Araştırmaları Dergisi, 5(1), 124-138.

Katehi, L., Pearson, G., \& Feder, M. (2009). The status and nature of K-12 engineering education in the United States. The Bridge, 39(3), 5-10.

Lee, J. W., Park, H. J., \& Kim, J. B. (2013). Primary teachers' perception analysis on development and application of STEAM education program. Journal of Korean Elementary Science Education, 32(1), 47-59. https://doi.org/10.15267/keses.2013.32.1.047

McPherson, S. \& Anid, N.M. (2014). Preparing STEM Teachers for K-12 Classrooms: Graduate Certificate Evaluation and Innovation. [Available online at: https://ieeexplore.ieee.org/stamp/stamp.jsp?arnumber=6891035] Retrieved on June 09, 2019.

Kennedy, M. M., Ahn, S., \& Choi, J. (2008). The value added by teacher education. In M. CochranSmith, S. FeimanNemser, and J. McIntyre (Eds), Handbook of research on teacher education: enduring issues in changing contexts (pp. 1249-1273) Mahwah, NJ: Lawrence Erlbaum Associates, Inc.

Merriam, S.B. (2009). Qualitative research. A guide to design and implementation (2th ed.). San Francisco, CA: Jossey-Bass.

Miles, M.B., \& Huberman, A.M. (1994). Qualitative data analysis (2th ed.). Thousand Oaks, CA: Sage.

Milner-Bolotin, M. (2018) Evidence-based research in STEM teacher education: From theory to practice. Frontiers in Education, 3(92), 1-9. https://doi.org/10.3389/feduc.2018.0009

Morrison, J. S. (2006). TIES STEM education monograph series: attributes of STEM education. [Available online 
Education/Attributes\%20of\%20STEM\%20Education\%20with\%20Cover\%202\%20.pdf] Retrieved on April 01, 2019.

Nagdi, M.E., Leammukda, F., \& Roehrig, G. (2018). Developing identities of STEM teachers at emerging STEM schools. International Journal of STEM Education, 5(36), 2-13. https://doi.org/10.1186/s40594-018-0136-1

National Research Council. (2011). Successful STEM education: A workshop summary. Washington, DC: National Academies Press.

National Science Foundation. (2014). NSF Approved STEM Fields. [Available online at: https://www.btaa.org/docs/default-source/diversity/nsf-approved-fields-ofstudy.pdf?sfvrsn=1bc446f3 2 2 ] Retrieved on April 1, 2019.

Noh, H. J., \& Paik, S. H. (2014). STEAM experienced teachers' perception of STEAM in secondary education. Journal of Learner-Centered Curriculum and Instruction, 14(10), 375-402.

Ostler, E. (2012). 21st century STEM education: a tactical model for long-range success. International Journal of Applied Science and Technology, 2(1), 28-33.

Pang, J., \& Good, R. (2000). A review of the integration of science and mathematics: Implications for further research. School Science and Mathematics, 100(2), 73-82. https://doi.org/10.1111/j.19498594.2000.tb17239.x

Patton, M. (2002). Qualitative evaluation and research methods. Beverly Hills, CA: SAGE.

President's Council of Advisors on Science and Technology. (2010). Prepare and inspire: K-12 education in science, technology, engineering, and math (STEM) for America's future. Washington, DC: Author. [Available online at: http://www.whitehouse.gov/sites/default/files/microsites/ostp/pcaststemed-report.pdf] Retrieved on June 29, 2019.

Reeve, E. (2015). STEM thinking!. Technology and Engineering Teacher, 74(4), 8-6.

Ring, E.A., Dare, E.A., Crotty, E.A., \& Roehrig, G.H. (2017). The evolution of teacher conceptions of stem education throughout an intensive professional development experience. Journal of Science Teacher Education, 28(5), 444-467. https://doi.org/10.1080/1046560X.2017.1356671

Rinke, C. R., Gladstone-Brown, W., Kinlaw, C. R., \& Cappiello, J. (2016). Characterizing STEM teacher education: Affordances and constraints of explicit STEM preparation for elementary teachers. School Science and Mathematics, 116(6), 300-309. https://doi.org/10.1111/ssm.12185

Silverman, D. (2013). Doing qualitative research: A practical handbook. London: SAGE Publications.

Stinson, K., Harkness, S., Meyer, H., \& Stallworth, J. (2009). Mathematics and science integration: models and characterizations. School Science and Mathematics, 109(3), 153-161. https://doi.org/10.1111/j.1949-8594.2009. tb17951.x

Stohlmann, M., Moore, T.J., \& Roehrig, G. H. (2012). Considerations for teaching integrated STEM education. Journal of Pre-College Engineering Education Research (J-PEER), 2(1), 28-34. https://doi.org/10.5703/1288284314653

Supovitz, J. A., \& Turner, H. M. (2000). The effects of professional development on science teaching practices and classroom culture. Journal of Research in Science Teaching, 37(9), 963-980. https://doi.org/10.1002/1098-2736(200011)37:9<963::AID-TEA6>3.0.CO;2-0

Timur, B., \& İnançli, E. (2018). Science teacher and teacher candidates' opinions about stem education. International Journal of Science and Education, 1(1), 48-66.

Tosmur-Bayazit, N., Akaygün, S., Demir, K., \& Aslan-Tutak, F. (2018). Bir STEM öğretmen eğitimi örneği: yenebilir arabalar etkinliğinin öğretmen eğitimi açısından incelenmesi [An Example of STEM Teacher Professional Development: Exploration of Edible Cars Activity from Teacher Education Perspective]. Fen Bilimleri Öğretim Dergisi, 6(2), 213-232.

Türk, N., Kalayc1, N., \& Yamak, H. (2018). New trends in hinger education the globalizing World: STEM in teacher education. Universal Journal of Educational Research 6(6), 1286-1304. https://doi.org/10.13189/ujer.2018.060620 
Türk Dil Kurumu (2019). Türk dil kurumu sözlükleri. [Çevrim-içi: https://sozluk.gov.tr/], Erişim tarihi: 23.12.2019.

U.S. Department of Education (2010). A Blueprint for Reform: The Reauthorization of the Elementary and Secondary Education Act. [Available online at: https://www2.ed.gov/policy/elsec/leg/blueprint/blueprint.pdf] Retrieved on May 15, 2019.

Wang, H. H., Moore, T. J., Roehrig, G. H., \& Park, M. S. (2011). STEM integration: Teacher perceptions and practice. Journal of Pre-College Engineering Education Research (J-PEER), 1(2), 1-13. https://doi.org/10.5703/1288284314636

Yıldırım, A., \& Şimşek, H. (2011). Sosyal bilimlerde nitel araştırma yöntemleri. İstanbul: Seçkin Yayınları.

Yıldırım, B. (2018a). Research on teacher opinions on STEM practices. Eğitim Kuram ve Uygulama araştırmaları Dergisi, 4(1), 42-53.

Yıldırım, B. (2018b). 2023, 2053 ve 2071 hedefleri için STEM eğitim raporu. [Çevrim-içi: http://bystemegitimi.com/img/VSgmdXhL.pdf], Erişim tarihi: 30.06.2019.

Yıldırım, B. (2017). Fen eğitiminde STEM. M. P. Demirci Güler (Ed.). Fen bilimleri öğretimi (pp. 283295). Ankara: Pegem Akademi.

Yıldırım, B., \& Selvi, M. (2016). Examination of the effects of STEM education integrated as a part of science, technology, society and environment courses. Journal of Human Sciences, 13(3), 36843695. https://doi.org/10.14687/jhs.v13i3.3876

Yıldırım, B., \& Şahin-Topalcengiz, E. (2019). STEM pedagogical content knowledge scale (STEMPCK): A validity and reliability study. Journal of STEM Teacher Education, 53(2), 1-20. https://ir.library.illinoisstate.edu/jste/vol53/iss $2 / 2$

Yin, R. K. (2017). Case study research and applications: Design and methods. Los Angeles: SAGE. 


\section{Extended Abstract}

\section{Introduction}

One of the most important factors in the implementation of STEM education in formal and informal education environments is the teacher. The teacher plays a vital role in encouraging and preparing the students for education (Braga, 1972; Gökdere, \& Cepni, 2003). The fact that the teacher has a vital place in the education system indicates that the teachers have an important role in the implementation of STEM education in the classes. Therefore, U.S. Department of Education (2010) emphasizes that the preparation of K-12 teachers for the teaching of STEM education is a national priority and emphasizes the need for a program for STEM education since the preparation of qualified teachers in STEM education is important for the students to reach high academic standards. For example, considering that the science and mathematics competences of the teachers are related to the achievement of the students (Hibpshman, 2007), it can be stated that there is a relationship between STEM education qualifications of the teachers and student achievement. However, the lack of professional development programs required for the teachers to gain knowledge about STEM education causes the students to perform poorly (Ejiwale, 2013). As a matter of fact, it is important for the teachers to master the subject in order to achieve STEM integration successfully and to be applied in classes (Pang, \& Good, 2000). The lack of sufficient knowledge of the field in most teachers makes it difficult to achieve STEM integration (Stinson Harkness, Meyer and Stallworth, 2009). The knowledge of field and pedagogy is important for effective teaching (Stohlmann, Moore, \& Roehrig, 2012). As a matter of fact, Margot and Kettler (2019) emphasized that the teachers should be supported with STEM training professional development programs in order to realize effective STEM teaching. These situations led to the preparation of professional development programs for the training of STEM teachers (Ejiwale, 2013). Therefore, STEM education professional development programs should be planned for the teachers to implement STEM education in their own classes (Du et al., 2018).

Therefore, it is necessary to focus at first degree on the professional development programs in providing the necessary skills for STEM education. However, most of the professional development programs do not meet the professional development needs of the teachers because they are carried out in short-term periods (Rinke, Gladstone-Brown, Kinlaw, \& Cappiello, 2016). When the related literature is examined, it is emphasized that it is important that the teachers should have at least 80 hours of training time in order to ensure their professional development and that it is important to integrate this period into the academic year in order to enable the teachers to apply this knowledge they have learned in their classes and to support their practices in the class (Jhonson, \& Fargo, 2010; Supovitz, \& Turner, 2000). In this context, the purpose of this study is to propose the STEM Teacher Institutes Education Model (STIEM) to ensure the professional development of teachers through STEM education.

\section{Method}

Within the scope of the research, STIEM was proposed so as to improve the professional competence of the teachers regarding STEM education. For this purpose, the research was designed in accordance with the case study design among the qualitative research methods. The 
study group of the research consisted of 40 teachers working in one of the metropolitan cities located in Turkey.

STIEM model was developed according to ADDIE design model (Dick and Carey, 1996). ADDIE is an educational design model consisting of five stages: Analyze, Design, Develop, Implement, and Evaluate. The model was developed in accordance with the ADDIE model. The documents, semi-structured interview form, and lesson plans were used to reveal the stages of STIEM model in the study. The qualitative data obtained in the study were analyzed through the content analysis method. The data were collected through voice recordings and semi-structured interviews. The obtained records were transferred to the manuscript with the help of a researcher and an expert. The analysis and interpretation of these data were carried out in four stages. These stages are processing the data obtained from the documents, coding the data, arranging the codes, defining the findings, and interpretation (Yıldırım, \& Şimşek, 2011).

\section{Findings}

Such stages as STEM Education Literacy (SEL), Identifying Needs (IN), Determining Objectives (DO), Selecting Content (SC), Determining Educators and Their Characteristics (DETC), Preparing Lesson Plan (PLP), Practice (P), and Evaluation (E) were determined as a result of document analysis.

Findings were acquired under 11 themes such as competence in STEM education, characteristics paid attention to in lesson plan, difficulties in preparing lesson plan, ease of studying as a group, university education, undergraduate education, difficulties experienced in practice, STEM literacy, characteristics of STEM literate individuals, trainers who will give STEM education, and characteristics of these trainers.

In the lesson plans, the findings were in detail obtained under the themes of conformity to STEM fields, conformity to the nature of STEM education, conformity to teaching-learning processes, conformity in terms of time, conformity to class level, and conformity to applicability and connection with daily life.

\section{Discussion and Conclusion}

The first finding within the scope of the study is related to the results of document analysis. As a result of the document analysis, it was emphasized that such stages as STEM education literacy, identification of the needs, determination of the goals, content selection, definition of the trainers and their characteristics, preparation of lesson plan, practice, and evaluation should be available so as to ensure STEM professional development of the teachers. The second finding in this research is related to the opinions of teachers. In this context, the teachers stated that they did not feel sufficient about STEM education. The teachers especially emphasized that their undergraduate education was not sufficient. The teachers also emphasized that they should have been provided with coding education, science, engineering, educational technologies, curriculum development, and lesson plan preparation trainings. When the related literature is examined, it is obsrved that STEM field and pedagogy knowledge has an important place in teacher training (Kennedy, Ahn, \& Choi, 2008; Murphy, \& Mancini-Samuelson, 2012; Stohlmann, Moore, \& Roehrig, 2012; Wang, Moore, Roehring, \& Park, 2011). 
Another result acquired within the scope of the second finding is related to the characteristics taken into consideration in preparing the lesson plan. The teachers stated that they paid attention to the integration of different disciplines, the gains in the curriculum, compliance with the student level, time and teaching-learning processes. In addition, while preparing lesson plans, the teachers mentioned that they had problems in the integration of field knowledge, engineering design processes, time, technology, and 21st century skills. Another result obtained in this context is related to the problems encountered by the teachers during STEM practices. The teachers said that they had problems in practice due to lack of time, lack of material, lack of student readiness, and high class availability. As a matter of fact, it is emphasized in the literature that the teachers experience problems during STEM education (Jho et al., 2016; Y1ldırım, 2018a).

All of the teachers stated that they were not STEM literate individuals. The teachers defined STEM literate individuals as those who work interdisciplinary, produce new and different products, read constantly, and master in STEM fields. In addition, the teachers emphasized that STEM trainings should be provided by educators, field experts, engineers, and software developers. Moreover, the teachers mentioned that the people who will provide STEM trainings should be experts in the field, interdisciplinary employees, flexible and creative, guiding and have leader spirit. The third finding obtained within the scope of the study is related to the analysis of lesson plans. It was understood that the majority of the lesson plans individually prepared by the teachers did not cover all STEM fields. 